Working Paper 2008:7

Department of Economics

\title{
Selfish and Prospective Theory and Evidence of Pocketbook Voting
}

Mikael Elinder, Henrik Jordahl and Panu Poutvaara 
Department of Economics

Uppsala University

P.O. Box 513

SE-751 20 Uppsala

Sweden

Fax: $+{ }_{4} 6184711478$
Working paper 2008:7

October 2008

ISSN $1653-6975$

Selfish And Prospective

Theory And Evidence of Pocketbook Voting

Mikael Elinder, Henrik Jordahl and Panu Poutvaara

Papers in the Working Paper Series are published on internet in PDF formats. 


\title{
Selfish and Prospective
}

\section{Theory and Evidence of Pocketbook Voting*}

\author{
Mikael Elinder, ${ }^{\text {a Henrik Jordahl, }}{ }^{\text {b Panu Poutvaara }}{ }^{c}$
}

October 14, 2008

\begin{abstract}
We present and test a theory of prospective and retrospective pocketbook voting. Focusing on two large reforms in Sweden, we establish a causal chain from policies to sizeable individual gains and losses and then to voting. The Social Democrats proposed budget cuts affecting parents with young children before the 1994 election, but made generous promises to the same group before the 1998 election. Since parents with older children were largely unaffected we use a difference-in-differences strategy for identification. We find clear evidence of prospective pocketbook voting. Voters respond to campaign promises but not to the later implementation of the reforms.
\end{abstract}

Keywords: Elections, Economic voting, Pocketbook voting, Self-interest, Prospective voting, Retrospective voting, Child care

JEL Classification: C21, D72, H50

\footnotetext{
* The authors wish to thank Niclas Berggren, Sören Blomquist, Momi Dahan, Matz Dahlberg, Vincenzo Galasso, Alexander Gelber, Colin Jennings, Andrew Leigh, Che-Yuan Liang, Assar Lindbeck, Heléne Lundqvist, Dario Maimone, Hannu Nurmi, Tuomas Pekkarinen, Tobias Seidel, Håkan Selin, Pilar Sorribas Navarra, Hannu Vartiainen, Johan Vikström, and participants at the annual meeting of the Public Choice Society in San Antonio, the CESifo Public Sector area conference in Munich, the first Summer School in Public Economics in Barcelona, the IIPF annual congress in Maastricht, and the EEA annual congress in Milan, as well as seminar participants at the Ratio Institute, the Research Institute for Labor Market Policy Evaluation (IFAU), the Research Institute of Industrial Economics (IFN), Uppsala University, the University of Vienna and the Institute for Advanced Studies joint seminar, and the Public Choice Research Centre in Turku for helpful comments and suggestions, as well as Johan Fihn for providing data from the Swedish Election Studies. Elinder and Jordahl gratefully acknowledge financial support from the Jan Wallander and Tom Hedelius Foundation. Poutvaara gratefully acknowledges hospitality by the Center for Economic Studies in Munich during the writing process.

${ }^{a}$ Uppsala University. Address: Department of Economics, Box 512, SE-751 20 Uppsala, Sweden. Email: mikael.elinder@nek.uu.se.

${ }^{\mathrm{b}}$ Research Institute of Industrial Economics (IFN). Address: Box 55665, SE-102 15 Stockholm, Sweden. Email: henrik.jordahl@ifn.se.

${ }^{\mathrm{c}}$ University of Helsinki and CEBR. Address: Department of Economics, P.O. Box 17 (Arkadiankatu 7), FIN-

00014 University of Helsinki, Finland. Email: panu.poutvaara@helsinki.fi.
} 


\section{Introduction}

The idea that voting behavior is determined by material self-interest is a fundamental assumption in numerous economic models, with the Meltzer and Richard (1981) paradigm of redistribution as a prominent example. In contrast, the empirical evidence in favor of selfinterested voting is surprisingly weak. Lewis-Beck and Stegmaier (2007) note that there are about 400 published studies on economic voting, and conclude that the cumulative support for "pocketbook voting" is marginal at best. Pocketbook voting usually refers to self-interested economic voting in general, but the empirical tests have typically relied on the specific assumption that voters attribute all changes in their financial situations to the policies of the incumbent government. ${ }^{1}$ While judging the incumbent government by one's own pocketbook can be a useful information shortcut in some cases, there are plenty of confounding factors. For example, it appears implausible that a voter should be more inclined to support the incumbent government if she earns more money after having graduated, or for some other reason that is unrelated to government policy. ${ }^{2}$ In this paper we introduce a new approach to investigate the empirical relevance of pocketbook voting.

We start out by presenting a theory of pocketbook voting in which citizens respond to the influence of proposed or implemented policies on their personal economic situation. The model allows for both prospective and retrospective voting. Prospective voting means that voters base their expectations of future policies on electoral platforms. Retrospective voting means that they base them on past performance. ${ }^{3}$

In the empirical investigation we establish a causal chain from policy proposals to sizeable individual gains and losses, and in a second step from individual gains and losses to voting. As mentioned above, this link from expected policies to personal finances has been missing in previous empirical studies. We identify a group of voters who are affected by two significant policy shifts. Parents with young children were singled out for a relatively unfavorable treatment according to the electoral platform of the Swedish Social Democratic Party before the 1994 election, but were given especially generous promises by this party just before the 1998 election. By comparing parents with young and parents with older children (who were largely unaffected by the policy changes) we obtain exogenous variation in the gains and losses from the reforms.

Since both reforms were implemented during the following parliamentary term we discriminate between prospective and retrospective voting by tracking the votes of parents with young and parents with older children over several elections. The emerging voting pattern provides striking evidence of prospective pocketbook voting. Parents with young children respond when the reforms appear as election campaign promises, and not when the reforms are later implemented. While our study of two groups of parents is primarily designed to identify the causal effect of public expenditures on individual voting, some tentative calculations show that pocketbook voting may be an important determinant of election outcomes. At face value, our estimates suggest that the generous promise to parents with

\footnotetext{
${ }^{1}$ Empirical studies in this literature include Fiorina (1978), Kinder and Kiewiet (1979), Markus (1988, 1992), Alvarez and Nagler (1995, 1998), Nadeau and Lewis-Beck (2001), and Jordahl (2006).

${ }^{2}$ Gomez and Wilson (2001) acknowledge the diffuse attribution in traditional tests of pocketbook voting, but rather than focusing on how policies affect personal finances, they argue - somewhat paradoxically - that only the politically sophisticated let the development of their personal finances determine how they vote.

${ }^{3}$ Hibbs (2006) provides an informative overview of retrospective and prospective voting in macroeconomic models. MacKuen et al. (1992) show that the time series of presidential approval can be accounted for by the prospective economic expectations of American voters, but not by their retrospective economic experiences.
} 
young children resulted in an electoral gain of approximately 1.5 percentage points for the left bloc of parties in the 1998 election. Such an increase exceeds the margin of victory in 5 out of 19 Swedish postwar elections.

A few previous studies provide related evidence from varying applications and settings. To start with, self-interested voting is a keystone in theoretical models of tactical redistribution (Lindbeck and Weibull, 1987; Dixit and Londregan, 1996). Dahlberg and Johansson (2002) provide empirical support for the prediction that governments tactically target redistribution to swing voters, suggesting that influential politicians believe that citizens vote their pocketbooks. Levitt and Snyder (1997) find that federal spending on assistance programs in a U.S. congressional district benefits the congressional incumbent electorally. However, they do not find any effect from direct transfers to individuals. From our theoretical perspective of pocketbook voting, one explanation for this could be that they do not control for how incumbents have voted on entitlement programs. Edlund and Pande (2002) provide a motivation for studying pocketbook voting based on the U.S. political gender gap. They trace the rise of this gender gap to the decline in marriage and argue that the rising support for the Democratic Party among women can be explained by selfish preferences for redistribution driven by changes in personal income.

In a recent paper, Richter (2006) analyzes economic voting in the Russian presidential election of 1996, which was branded as a fundamental choice between capitalism and communism. Despite repeated orders by President Yeltsin to pay off wage arrears, every other worker in the private and public sector experienced nonpayments of wages at the time of the election. Richter uses a matching model to demonstrate that workers whose wages were not paid in time were less likely to vote for the incumbent president. Unlike Richter, we study a mature democracy and compare prospective with retrospective voting.

Other explanations of voting behavior include group voting (Mutz and Mondak, 1997), social background (Campbell et al., 1960), beliefs about the causes of income (Fong, 2001; Alesina and Angeletos, 2005), and voting responses to the macroeconomy (Fair, 1978). While we cannot compare the importance of pocketbook voting with other voting models macroeconomic voting in particular - an advantage with our empirical strategy is that none of the alternative explanations confounds our estimates.

\section{Theoretical framework}

Previous empirical studies have been quite vague when it comes to defining prospective and retrospective voting. To formally define those central concepts and to provide structure for the empirical investigation, we start by developing a theoretical framework of pocketbook voting. ${ }^{4}$

We analyze voter choices between two political parties, denoted by L for the party on the left and $\mathrm{R}$ for the party on the right. We take as our starting point Persson and Tabellini's (2000) workhorse model of probabilistic voting in which it is assumed that promises made by political parties are always fulfilled. We extend the model by allowing voters to regard promises as non-binding. As our focus is on introducing a theoretical framework that allows for empirical tests of different hypotheses about voting behavior, we take party platforms as

\footnotetext{
${ }^{4}$ The major previous contributions are Downs (1957), Key (1966), and Fiorina (1981). A common feature of these models is that voters do not care about promises. Nor is it the case that the agency approach to elections and politics championed by Besley (2006) leaves any room for promises.
} 
given. Our approach is compatible with different views on party behavior, including both office-motivations and ideological considerations.

\subsection{Voting with given expected policies}

For simplicity, we analyze the likelihood that citizen $j$, belonging to an identifiable group $m$, votes for party L. The group index is meant to capture the fact that large amount of transfers are targeted to specific groups, like parents of young children, pensioners, or people registered as unemployed. We denote the gross income that citizen $j$ receives in period $t$ by $Y_{j, t}$. A period is defined so that it includes both an electoral campaign and the subsequent parliamentary term. The political parties present their platforms at the beginning of the period. After this, citizens vote and the winner forms the government. During the rest of the period, the government decides on tax schedules and income transfers, and the incomes of the citizens are realized.

We denote the after-tax income that citizen $j$ would receive if party $\mathrm{K}, K \in\{L, R\}$, were in power by $N_{t}^{K}\left(Y_{j, t}\right)$. This net income is calculated in the absence of group-specific transfers, and it does not have group-specific indices, to capture the idea that the income tax schedule is typically independent of age, and many other demographic characteristics that affect transfers. The benefits that members of group $m$ would receive if party $\mathrm{K}$ were in power are denoted by $B_{m, t}^{K}$. We also allow for a general popularity parameter in favor of party $\mathrm{L}$ in period $t$, denoted by $\kappa_{\mathrm{t}}$. Popularity is allowed to vary between elections and could take either positive or negative values. It reflects issues like perceived competence or likability of current party leaders.

Finally, citizens have (unobservable) individual-specific ideological preferences. Without loss of generality, we denote ideological preference of citizen $j$ in favor of party $\mathrm{L}$ by $z_{j}$, negative values implying an ideological preference in favor of party $\mathrm{R}$. The ideological preference incorporates different ways in which the parties may differ. In addition to economic policy, voters may care, to varying extents, on social issues, environmental regulation, and foreign policy. In line with Persson and Tabellini (2006), we further assume that utility has a linearly additive structure. We can now write the expected utility of citizen $j$ in group $m$ of having party $\mathrm{L}$ in power as

$E\left(U_{j, t}^{L}\right)=E\left(N_{t}^{L}\left(Y_{j, t}\right)\right)+E\left(B_{m, t}^{L}\right)+\kappa_{t}+z_{j}$.

Likewise, the expected utility of having party $\mathrm{R}$ in power is

$E\left(U_{j, t}^{R}\right)=E\left(N_{t}^{R}\left(Y_{j, t}\right)\right)+E\left(B_{m, t}^{R}\right)$.

We assume that citizens vote for the political party giving the higher expected utility. From Equation (1) and (2), citizen $j$ in group $m$ prefers party L if:

$E\left(N_{t}^{L}\left(Y_{j, t}\right)\right)+E\left(B_{m, t}^{L}\right)+\kappa_{t}+z_{j}>E\left(N_{t}^{R}\left(Y_{j, t}\right)\right)+E\left(B_{m, t}^{R}\right)$.

We next define a shorter term to denote the expected monetary difference in after-tax income from party L being in office (relative to party $\mathrm{R}$ ) for voter $j$ : 
$E\left(M_{j, t}\right)=E\left(N_{t}^{L}\left(Y_{j, t}\right)-N_{t}^{R}\left(Y_{j, t}\right)\right)$

Rearranging (3) and using (4), we obtain

$E\left(M_{j, t}\right)+E\left(B_{m, t}^{L}-B_{m, t}^{R}\right)+\kappa_{t}+z_{j}>0$.

The inequality in (5) tells us that the choice between party $\mathrm{L}$ and party $\mathrm{R}$ depends on the difference in after-tax income between the $\mathrm{L}$ and $\mathrm{R}$ platforms, the difference in transfers between the $\mathrm{L}$ and $\mathrm{R}$ platforms, the general popularity parameter in favor of $\mathrm{L}$, and the citizen-specific ideological preference for L. Citizen $j$ votes for $\mathrm{L}$ if and only if the sum of these terms is positive. The term $E\left(M_{j, t}\right)+E\left(B_{m, t}^{L}-B_{m, t}^{R}\right)$ measures the pocketbook voting motivation in favor of party L. We simplify the analysis by assuming that the expected monetary difference in after-tax income between the $\mathrm{L}$ and $\mathrm{R}$ platforms is the same for all individuals, denoted by $\bar{M}$. Under this assumption, we can obtain a cutoff ideological preference parameter $\hat{z}_{m, t}(\bar{M})$ that denotes the group-specific ideological threshold above which a citizen votes for $\mathrm{L}:{ }^{5}$

$\hat{z}_{m, t}(\bar{M})=-\bar{M}-E\left(B_{m, t}^{L}-B_{m, t}^{R}\right)-\kappa_{t}$.

If we further follow Persson and Tabellini (2000) and assume that the ideological preference parameter $z$ follows a uniform distribution on the interval $[z, \bar{z}]$, we can use equation (6) to calculate the vote share that party $\mathrm{L}$ receives. To allow for different ideological preferences in different groups, we assume a group specific uniform distribution of $z_{m}$ on $\left[\underline{z_{m}}, \overline{z_{m}}\right]$. The probability that a citizen belonging to group $m$ votes for party $\mathrm{L}$ is given by equation (7):

$Q_{m, t}=\frac{\hat{z}_{m, t}(\bar{M})-\underline{z_{m}}}{\overline{z_{m}}-\underline{z_{m}}}$.

\subsection{Policy expectations}

So far, we have taken citizens' expectations concerning policies to be implemented as given. The next step is to formalize how expected policies are related to party platforms and previous policies. We allow for four components in citizens' expectations. First, the two parties have an underlying ideology. We denote the monetary benefits that group $m$ expects from party $K$, based on the latter's ideology, by $I_{m}^{K}$. This permanent component takes into account that some groups of citizens may be associated with one of the parties, like labor unions with the left party and entrepreneurs with the right party, or that some groups expect equally generous transfers from both parties, as might be the case with pensioners.

\footnotetext{
${ }^{5}$ At the cost of notational complexity, we could specify groups corresponding to different income ranges. The subsequent analysis would then be written separately for individuals belonging to each income range. In the empirical part of the paper, we first present results when ignoring income differences (arguing that we compare two groups with similar incomes), and then show in appendix B that controlling for income differences does not change the qualitative results.
} 
Second, citizens may react to electoral promises. We measure the promise-dependent expectation component, $G_{m, t}^{K}$, as the difference between party K's platform, denoted by $P_{m, t}^{K}$, and permanent ideological component, $I_{m}^{K}: G_{m, t}^{K}=P_{m, t}^{K}-I_{m}^{K}$. The variable $G_{m, t}^{K}$ thus measures how generous promises party $\mathrm{K}$ makes to group $m$ in period $t$, relative to what group $m$ could expect, based on party ideology.

Third, citizens may at least partly base their expectations on a party's track record of implemented policies. If party $K$ formed the government in period $t-1$, we denote by $H_{m, t-1}^{K}$ the difference between the transfers that it gave to group $m$, and what the party's ideology gives reason to expect: $H_{m, t-1}^{K}=B_{m, t-1}^{K}-I_{m}^{K}$. If party $\mathrm{K}$ was in opposition in period $t-1$, we define $H_{m, t-1}^{K}=0$. As an opposition party cannot implement policies, citizens cannot observe its realized generosity toward their group.

Fourth and finally, we allow for the possibility that citizens may respond to differences between implemented policies by the governing party and its previous electoral promises. If party $K$ formed the government in period $t-1$, we define as a term measuring deviation between implemented policies and electoral promises: $J_{m, t-1}^{K}=B_{m, t-1}^{K}-P_{m, t-1}^{K}$. If $\mathrm{K}$ was not in the government, we define $J_{m, t-1}^{K}=0$.

To facilitate the empirical investigation, we assume a simple additive structure of expectations as a function of these terms:

$$
E\left(B_{m, t}^{K}\right)=I_{m}^{K}+\lambda G_{m, t}^{K}+\mu H_{m, t-1}^{K}+\chi J_{m, t-1}^{K}
$$

where $\lambda$ is the weight that the citizen attaches to the platform of party $K$, relative to what the citizen expects from party $K$ based on ideology, $\mu$ measures the extent to which expectations of the governing party's future policies react to its generosity, relative to its ideological standpoint, during the concluding term, and $\chi$ measures the extent to which expectation of the governing party's future policy reacts to difference between its past policy and past platform. It is reasonable to expect that $0 \leq \lambda, \mu, \chi \leq 1$, and that $0 \leq \lambda+\mu \leq 1$. $^{6}$ It is natural to interpret $\lambda$ as the likelihood that the winning party will implement its promises. In a political system with a high level of trust and credible party promises, $\lambda$ would approach unity, while it would be close to zero in the opposite case.

Equation (8) is general enough to allow as special cases different views on political competition and the formation of expectations. If $\lambda=\mu=\chi=0$, then citizens would ignore both platforms and implemented policies, and base their expectations about future policies solely on the characteristics of the party's permanent ideology. If political platforms are viewed as cheap talk, then $\lambda=0$. We find it reasonable that under such circumstances $\chi=0$; if current electoral promises are considered to be cheap talk, so are past promises. If $\mu=0$, then citizens do not change their expectations about future policies of the governing party based on its current policies, while if $\mu>0$ voters expect that future policies are positively correlated with past policies. One way to motivate $\mu>0$ is that citizens may update their beliefs about the

\footnotetext{
${ }^{6}$ Allowing $\lambda+\mu$ to be larger than one could result in a peculiar case in which the political party in government could change a transfer toward a group and then state that it will maintain the new level of transfers, but with citizens expecting that the party would again change the transfer in the same direction.
} 
competence of the government, based on its past policies. Transfers which are more generous than expected from party ideology may signal either that the governing party is actually ideologically more favorable toward the targeted group than previously thought, or that the current party leadership is exceptionally generous. Exceptional generosity can depend on competence, tactical considerations or a combination of the two.

Inserting equation (8) into equation (5), we obtain the following condition for voting party L:

$$
\begin{aligned}
& z_{j}+E\left(M_{j, t}\right)+\left(I_{m}^{L}-I_{m}^{R}\right)+\lambda\left(G_{m, t}^{L}-G_{m, t}^{R}\right) \\
& +\mu\left(H_{t-1}^{L}-H_{t-1}^{R}\right)+\chi\left(J_{m, t-1}^{L}-J_{m, t-1}^{R}\right)+\kappa_{t}>0 .
\end{aligned}
$$

The inequality in (9) implies that citizens have both ideological and economic motivations, and that party choice also depends on how expectations are formed.

\subsection{Formalizing the pocketbook voting hypotheses}

For the empirical analysis, we can now specify two types of pocketbook voting. We view pocketbook voting as retrospective if $\mu>0$, and as prospective if $\lambda>0$. Pocketbook voting is only retrospective if $\lambda=0$ and $\mu>0$. Note that the idea of prospective pocketbook voting can be expected to imply also that $\chi>0$, i.e. that citizens roll back their support for political parties that do not deliver on their promises. ${ }^{7}$ We define prospective voting in a general form; the value of $\chi$ determines the degree to which citizens react to deviations from past promises by the government. We formalize the definitions of prospective and retrospective pocketbook voting as:

Definition 1. Citizens engage in retrospective pocketbook voting if $\mu>0$.

Definition 2. Citizens engage in prospective pocketbook voting if $\lambda>0$.

According to definition 1, retrospective pocketbook voting means that citizens react to implemented policies. ${ }^{8}$ According to definition 2, prospective pocketbook voting means that citizens are responsive to promises by political parties. ${ }^{9}$ The definitions imply that prospective and retrospective voting may coexist. It is left for the empirical analysis to evaluate their relative strength in cases where they push for different voting behavior. Therefore, definitions 1 and 2 translate into two testable hypotheses:

\footnotetext{
${ }^{7}$ If $\lambda>0$ and $\mu=\chi=0$, voters would be naive in the sense that a political party could increase its vote share by making generous promises to a certain group without ever implementing any promises.

${ }^{8}$ Conceptually, we can distinguish two types of retrospective voting: predictive and reactive. Our theoretical model describes retrospective voting of the predictive type. A predictive retrospective voter - as the name indicates - tries to find out which party she prefers to have in office for the next period. The prediction is based on current policies and not on electoral promises. A reactive retrospective voter is "purely retrospective" in the sense that she rewards or punishes the incumbent government based on how she is affected by policies, regardless of what she expects for the next period of office. As the predictions of the two types of retrospective voting are similar in our empirical setting, we lump them together under the label of retrospective voting throughout our empirical investigation.

${ }^{9}$ Parties have to earn credibility by keeping previous promises, and if they do not we expect $\lambda=0$. Although this reasoning implies that previous promises and implemented policies will feed into $\lambda$, we keep this parameter exogenous in the model. Credibility may change slowly and is in any case fixed in a given election. In consequence, we expect retrospective voting to be relatively more important in an environment of broken promises. An intriguing topic would be to estimate responses to broken promises. Since we study reforms that were implemented as promised, this has to be left for future research.
} 
Hypothesis 1. Assume that the government cuts (increases) benefits targeting group $m$, while it does not change benefits targeting group $n$. Then the electoral support for the government party decreases (increases) in group $m$, relative to group $n$, in the subsequent election.

Hypothesis 2. Assume that party $\mathrm{K}$ proposes cuts (increases) in benefits targeting group $m$, while it does not propose changes in benefits targeting group $n$. Then the electoral support for $\mathrm{K}$ should decrease (increase) in group $m$, relative to the support in group $n$, in the current election.

\subsection{From theory to empirics}

To start with, the fact that politics is multi-dimensional provides a major empirical challenge. In order to test our hypotheses and estimate the impact of a given policy, one should compare voting behavior between individuals who are similarly affected by other policies than the one under study. Furthermore, the citizens who are affected by a policy change should have voted as the comparison individuals if they had not been treated differently by the policy change. We have noted that the total pocketbook motivation in favor of party $\mathrm{L}$ is $E\left(M_{j, t}\right)+E\left(B_{m, t}^{L}-B_{m, t}^{R}\right)$. Our empirical approach will be to focus on the second term (transfers), and try to hold the first term (taxes) constant. This is accomplished by investigating voting responses to child care reforms among parents with young children compared with responses of parents with somewhat older children who were largely unaffected by the same reforms. The underlying idea is that the new child care policies affected the economic situation of parents with young children (the treatment group) to a much larger extent than parents with older children (the control group). From now on we denote the treatment group by $\mathrm{T}$ and the control group by $\mathrm{C}$. Without loss of generality, and in line with the empirical analysis, we focus on the case in which party L changes its platform and subsequently implements this change.

To connect our theoretical framework with the empirical difference-in-differences specification, we assume that the vote share of party L developed similarly in the treatment and in the control group before the policy change appeared as a new part of an election platform. ${ }^{10}$ Therefore, the ideological cutoff parameter that the individuals belonging to these groups face is the same before the treatment, for any given level of monetary difference in after-tax earned income: $\hat{z}_{T, t-1}(\bar{M})=\hat{z}_{C, t-1}(\bar{M})=\hat{z}_{t-1}(\bar{M})$. We also assume that the individualspecific ideological preference parameters follow the same uniform distribution in the treatment and control groups, so that $\underline{z}_{C}=\underline{z}_{T}=\underline{z}$ and $\bar{z}_{C}=\bar{z}_{T}=\bar{z}$. We can now write the probability that a voter belonging to the treatment (or control) group votes for $\mathrm{L}$ in period $\mathrm{t}-1$ as

$Q_{T, t-1}=Q_{C, t-1}=\frac{\hat{z}_{t-1}(\bar{M})-\underline{z}}{\bar{z}-\underline{z}}$.

As we analyze elections in which party $\mathrm{R}$ did not change its electoral platforms toward the treatment group or control group, and party $\mathrm{L}$ did not change its policies toward the control group, we assume that $E\left(B_{T, t-1}^{R}\right)=E\left(B_{T, t}^{R}\right), E\left(B_{C, t-1}^{R}\right)=E\left(B_{C, t}^{R}\right)$, and $E\left(B_{C, t-1}^{L}\right)=E\left(B_{C, t}^{L}\right)$. The probability that a citizen belonging to the control group votes for $\mathrm{L}$ in period $t$ is now

\footnotetext{
${ }^{10}$ Note, in passing, that this assumption is satisfied in our empirical analysis.
} 
$Q_{C, t}=\frac{\hat{z}_{t-1}(\bar{M})-\underline{z}}{\bar{z}-\underline{z}}+\frac{\kappa_{t}-\kappa_{t-1}}{\bar{z}-\underline{z}}$

The second term in equation (11) captures the effect of change in the general popularity parameter in favor of $\mathrm{L}$. The probability that a voter belonging to the treatment group votes for $\mathrm{L}$ is now

$Q_{T, t}=\frac{\hat{z}_{t-1}(\bar{M})-\underline{z}}{\bar{z}-\underline{z}}+\frac{\kappa_{t}-\kappa_{t-1}}{\bar{z}-\underline{z}}+\frac{E\left(B_{T, t}^{L}-B_{T, t-1}^{L}\right)}{\bar{z}-\underline{z}}$.

The third term of equation (12) captures the effect of changes in the expected benefit from L. Our basic difference-in-differences model can be written as

Vote $_{i, t}=\alpha+\beta \cdot T_{i}+\gamma \cdot p_{t}+\delta \cdot T_{i} \cdot p_{t}+\varepsilon_{i, t}$,

where Vote $_{i, t}$ is a dummy variable which equals 1 if at time period $\mathrm{t}(\mathrm{t}=1,2)$, respondent $\mathrm{i}$ votes for L. $T_{i}$ is a dummy variable taking the value 1 if the respondent belongs to the treatment group, and $p_{t}$ is a time period dummy that takes the value 0 in the election before and 1 in the election after the proposal or the policy change under study. The parameter of interest is $\delta$ which measures the effect of the policy changes on the treated group. $\alpha$ measures the fraction of voters in the control group that vote for $\mathrm{L}$ in the first period, $\beta$ accounts for differences in support for $\mathrm{L}$ in the first election between the treatment and control group. $\gamma$ captures the change in voting between the first and second election in the control group, and $\varepsilon_{i, t}$ is an error term. The parameters $\alpha, \beta, \gamma$ and $\delta$ arise from equations (10), (11) and (12) in the following way:

$\alpha=\frac{\hat{z}_{t-1}(\bar{M})-\underline{z}}{\bar{z}-\underline{z}} ; \beta=0 ; \gamma=\frac{\kappa_{t}-\kappa_{t-1}}{\bar{z}-\underline{z}} ; \delta=\frac{E\left(B_{T, t}^{L}-B_{T, t-1}^{L}\right)}{\bar{z}-\underline{z}}$.

Inserting equation (8) into the expression for $\delta$ in equation (14) gives

$\delta=\lambda \frac{G_{m, t}^{L}-G_{m, t-1}^{L}}{\bar{z}-\underline{z}}+\mu \frac{H_{t-1}^{L}-H_{t-2}^{L}}{\bar{z}-\underline{z}}+\chi \frac{J_{m, t-1}^{L}-J_{m, t-2}^{L}}{\bar{z}-\underline{z}}$.

In equation (15), the first term measures the prospective voting response to changes in party L's platform. The second term measures the retrospective response to the generosity of party $\mathrm{L}$ if it were in the government. Note that $H_{t-2}^{L}$ refers to the generosity before the previous election, if $\mathrm{L}$ was in government at that time. This term captures the idea that voters reacted to what happened in period $t-2$ already in the election at the beginning of period $t-1$, and no longer in the election in period $t$. One potential explanation for such a limited memory is that politicians change over time, so that voters might not react to what happened in the more distant past. The third term refers to potential voter reactions in case $\mathrm{L}$ has deviated from its promises when being in government. 


\section{Two child care reforms}

Sweden is a welfare state characterized by high taxes and generous welfare benefits even compared with other Nordic countries. For decades, the Social Democratic Party has been the largest party and has usually formed a minority government supported by the (formerly Communist) Left Party. Since World War II, the centre-right parties received enough seats in Parliament to form a government only in four general elections (1976, 1979, 1991, and 2006), most of the time as a majority coalition.

We make use of the fact that parents with young children were promised diametrically different treatments in the 1994 and 1998 election platforms of the Social Democratic Party, whereas parents with older children were largely unaffected by these proposals. The details of this empirical strategy are spelled out in Section 4. In the rest of this section we give a brief description of the two child care reforms that appeared as election promises in 1994 and 1998, focusing on how the incidence differed between parents with younger and parents with older children. Both reforms were at the center of the national election campaigns in which they appeared, making it very likely that most citizens were aware of them.

\subsection{Financing the budget deficit}

In the early 1990s the Swedish economy ended up in a severe crisis combining a surge in unemployment and huge budget deficits. As a result, the political parties tried hard to persuade voters in the 1994 election campaign that they were able to deal with the budget crisis. The main proposals of the centre-right coalition government were cuts in pension benefits and a promise to be tougher on tax evasion and fraudulent behavior in the social welfare systems. Apart from a traditional, unspecific proposal of tax increases for high income earners, the Social Democratic Party also proposed an unexpected and detailed way of fighting the budget deficit: major cuts in public support to parents with young children. Three of the proposals were particularly disadvantageous for parents with young children.

First, the centre-right government coalition had introduced a child-raising allowance in 1994. Families with children between one and three years old who did not use publicly subsidized child care received a cash transfer of $€ 220$ (net of tax) per month. ${ }^{11}$ Both the Social Democratic Party and the Left Party opposed the introduction of the child-raising allowance and declared that they would repeal this law if they won the election. They won and the childraising allowance was abolished already from January 1, 1995.

Second, parents who care for sick children are entitled to compensation for lost labor income from the social insurance system. In the election campaign of 1994 the Social Democrats declared that they would introduce a day of qualification before compensation could be claimed so that the first day of caring would not be compensated. The proposal met severe criticism since it was claimed that lone mothers would suffer hard from this change. But the Social Democrats insisted that it was needed to balance the budget. At the time of the election in 1998 this part of the reform had not been implemented.

Figure 1 shows the average number of qualification days that would be imposed on parents with one child if the sickness pattern of children would be the same, after the introduction of the qualification day, as it was before. Clearly, parents with young children have more to lose

\footnotetext{
${ }^{11} 1 €$ equals about 9 SEK. Families with children who participated part time in public child care were entitled to a smaller subsidy.
} 
from a day of qualification, since young children are sick more often than older children. ${ }^{12} \mathrm{~A}$ typical worker that stays at home 2.5 times per year would loose about $€ 130$ per year (net of tax) if this change would be implemented. ${ }^{13}$

Figure 1. Average number of sickness periods with compensation per child in 1994

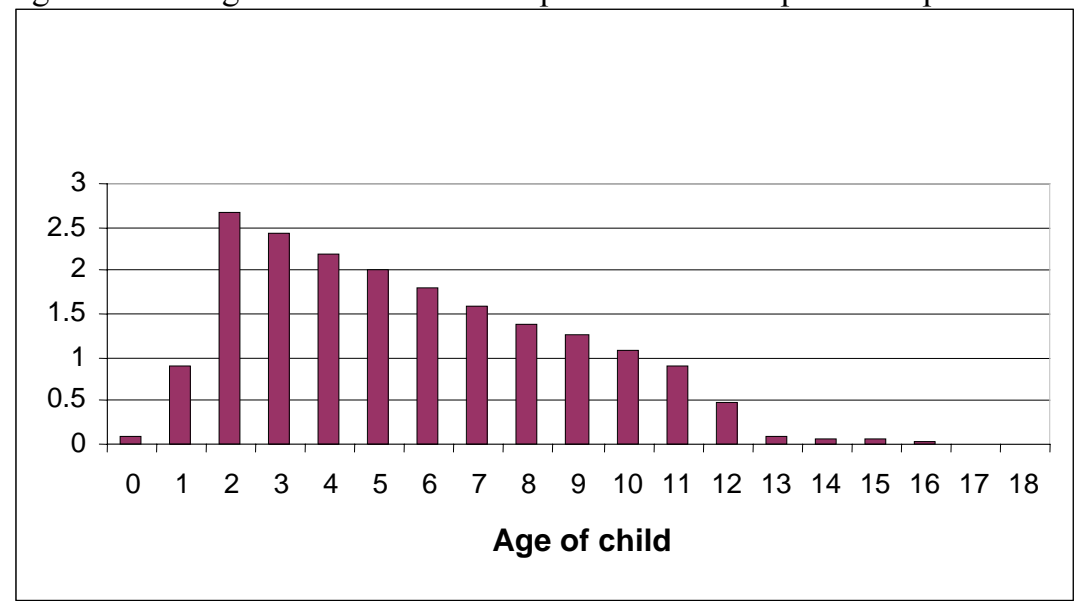

Source: The Swedish Social Insurance Agency

Third, in the summer of 1994 the Social Democrats unexpectedly proposed to reduce the compensation level in the parental insurance from 90 to 80 percent after the election. ${ }^{14}$ Such an initiative was at odds with a long left bloc tradition of generous compensations to parents but was well in line with most of the centre-right parties' policies, and can definitely be seen as a change in relative positions. ${ }^{15}$ After the election, the compensation was reduced to 80 percent from January 1995. For a parent working in the private sector this implied a loss of $€ 107$ per month net of tax, during parental leave. ${ }^{16}$

Together these three proposals constituted a child care reform which would significantly worsen the economic situation of parents with young children. The repeal of the child-raising allowance affected parents with children between 1 and 3 years. The introduction of a qualifying day for benefits when taking care of sick children would also primarily affect parents with young children. The reduction of benefits in the parental insurance almost exclusively affected parents with children aged 0 to 2 . There are strong reasons to believe that the described proposals mattered to voters. In a description of the 1994 election, Widfeldt (1995) highlights that promises of spending increases were absent in the campaign and that especially the Social Democratic Party's proposal to cut the public support for families with young children led to an intense debate.

\footnotetext{
12 The reason why there are so few sickness periods for children up to one year old is that one parent is typically not working and hence not entitled to compensation when caring for a sick child.

${ }^{13}$ Based on the average daily salary for private sector workers in 1995, which was $€ 76$, and a 30 percent tax rate.

${ }^{14}$ The Swedish parental insurance is very generous compared with other European countries. In 1994 parents could claim compensation for about one year's loss of earnings when staying at home with a newborn child. The compensation can be spread out over many years. In practice, however, a large majority of the compensation is claimed during the child's first or second year.

${ }^{15}$ The Liberal Party initially opposed the reduction in the compensation level, but after the Social Democrats had reached an agreement with the other centre-right parties they finally also supported the agreement.

${ }^{16}$ Based on a daily salary of $€ 76,20$ working days per month, and 30 percent tax rate,
} 


\subsection{The cap on child care fees}

In the election campaign of 1998, the Social Democratic Party promised to introduce a fee cap on child care services that would substantially reduce the child care fees for most families with young children. This reform targeted a well defined group of voters with a high take-up rate: in 1998 about 73 percent of all children aged 1 to 5 participated in publicly subsidized child care. ${ }^{17}$ Although child care fees had been discussed for some time, the electorate and even most Social Democrat ministers were surprised when a tangible reform proposal was presented as an election promise in the party's election manifesto. The manifesto had been prepared secretly by the Prime Minister and a few confidants, and was published one month before Election Day. It included the following promise:

No other group has carried the burden of the economic crisis as heavily as families with children. Not even the most unprotected and innocent - the children - were unaffected by the economic crisis. We have therefore increased child benefits and introduced free medical services for children. To further improve the situation of families with children, and to encourage more parents to start working or to increase their hours of work, we would like to implement a cap on child care fees in the entire country at SEK 700 [€ 78 per month] for the first child and with lower fees for subsequent children. The reduction in child care fees should be at least SEK 200 [€ 22] for everyone. A fee cap should also be introduced in after school recreation centers at SEK 500 [€ 56]. The municipalities will be compensated for their loss of revenues. ${ }^{18}$

The opposition did not support the idea of a cap on child care fees in the election campaign of 1998. In November 2000, the parliament voted in favor of introducing the fee cap reform. ${ }^{19}$ The parties belonging to the centre-right bloc presented different alternatives but did not agree on any counter-proposal. In his note on the 1998 election, Arter (1999) brings up the promise to reduce day care fees as one of the most important issues of the campaign.

The reform was implemented on January 1, 2002. All municipalities but two implemented the fee cap from the beginning and the remaining two did so one year later. ${ }^{20}$ The fee cap was set to a maximum of three percent of family gross income or $€ 127$ for the first child, two percent or $€ 84$ for the second child, and one percent or $€ 42$ for the third child, granted that they were all in child care. For additional children, child care was made free of charge. ${ }^{21}$

The fee cap substantially reduced the child care costs of many families. A family with a "normal" income and two children in child care 33 hours per week gained $€ 113$ per month in the municipality with median fees and $€ 238$ in the municipality with the highest fees in

\footnotetext{
${ }^{17}$ This statistic comes from the Swedish National Agency for Education (1999). Note however that the fraction of children who participate in publicly subsidized child care between the age of 2 and 5 is even larger than 73 percent since most of the children who do not participate in child care at a given time are under two years old. ${ }^{18}$ Taken from the 1998 election manifesto of the Social Democratic Party, "Med omtanke om framtiden Socialdemokraternas politik inför 2000-talet". (Our translation, the original text is in Swedish.) The mentioned changes in child benefits and medical fees had marginal economic consequences and also did no differ much between parents with young and parents with older children.

${ }^{19}$ Although The Left Party and The Green Party initially were against the reform, they voted with the Social Democrats.

${ }^{20}$ Child care is the responsibility of municipalities, but by compensating for lost revenues, the central government gave each municipality a strong incentive to adopt the cap on child care fees.

${ }^{21}$ Parents with children in after-school care also benefited from the reform, but to a considerably smaller degree. The reduction in after-school care fees was much smaller, and in addition fewer children attend after-school care.
} 
1999. ${ }^{22}$ These gains constitute approximately five and ten percent of the family's monthly net income.

It is evident that the fee cap reform would substantially improve the financial situation of a vast majority of families with young children. Specifically, parents with children aged 0 to 4 at the time of the election in 1998 would benefit the most from this election promise.

Figure 2 describes the timing of the election campaign promises and their implementation. Note the change of government in the 1994 election.

Figure 2. Timing of election promises and implementations

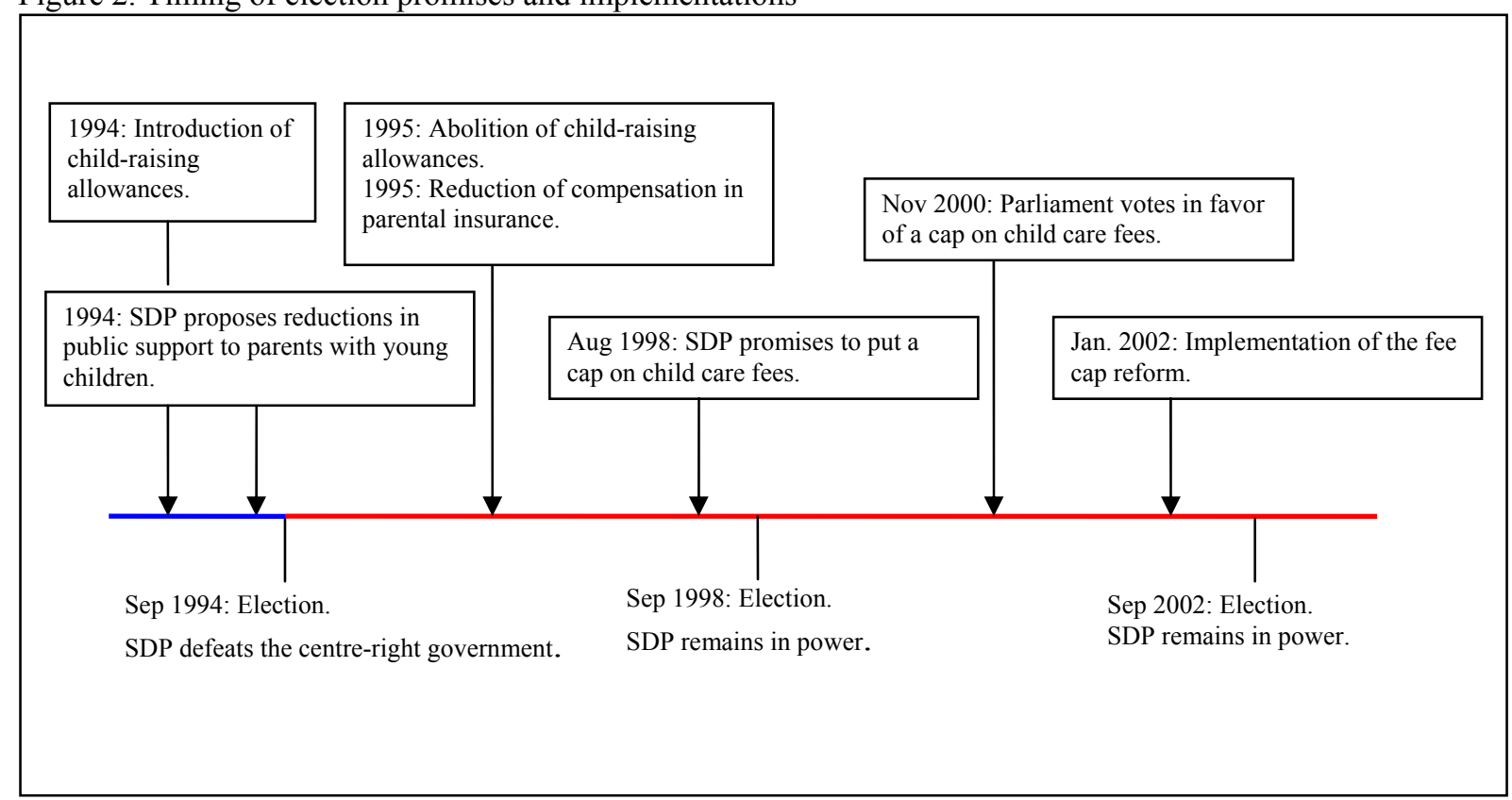

Note: SDP $=$ Social Democratic Party.

\section{Empirical strategy}

The two Swedish child care reforms (described in Section 3) are exceptionally well suited for testing the pocketbook voting hypothesis. First of all, since both reforms were described with unusual clarity in the election manifestos of the Social Democratic Party they provide a link from policies to individual gains and losses. Second, both reforms were implemented, allowing us to test whether voters responded to reform proposals already when they appeared as campaign promises, or only after they were implemented. ${ }^{23} \mathrm{~A}$ third attractive feature of the reforms is that significant individual benefits were at stake. Since elections are multidimensional, one should not expect to find empirical relationships between voting and minor economic issues.

\footnotetext{
${ }^{22}$ Fees before and after the reform for a family with a total monthly gross income of $€ 4,120$ in 1999 and $€ 4,630$ in 2002 and with two children in child care 33 hours per week. Figures are taken from The Swedish National Agency for Education (1999, 2003). Figures from 2002 are transformed to 1999 years prices (factor 0.946 from the CPI of Statistics Sweden).

${ }^{23}$ Several studies show that election promises are often delivered on. In the United Kingdom about 80 percent of the election promises of the winner are implemented, while in the United States the Democrats and Republicans implement about 60 percent of their election promises (Royed, 1996). For Sweden and in our period of study (1994-2002), Naurin (2008) reports that the Social Democrats have fulfilled about 60 percent of their election promises and partially fulfilled another 25 percent of them.
} 
We test the pocketbook voting hypotheses by estimating difference-in-differences models separately for 1991 to 1994, for 1994 to 1998, and for 1998 to 2002, using equation (13). In our baseline specification our dependent variable is the vote share of the left bloc of parties consisting of the Social Democratic Party and the Left Party. ${ }^{24}$ But we also present all empirical results for the vote share of the Social Democratic Party alone.

Our difference-in-differences model is given by equation (13), described in Section 2, where $\delta$ measures the effect of the policy changes on the treated group. Equation (14), which demonstrates how $\delta$ and the other parameters in the estimated equation (13) arise from the underlying theoretical model, is based on the assumption that there has not been any change in left bloc policies toward the treatment group (relative to the control group) in the previous election. This assumption is satisfied in the 1994 election. ${ }^{25}$ However, equation (13) holds also when there has been past policy changes, as in the elections of 1998 and 2002. The only difference in the empirical analysis is that in these latter elections, the terms $\alpha, \beta$, and $\gamma$ also reflect past policy changes, so that the prediction $\beta=0$ need not be satisfied. However, what matters is the estimated size and statistical significance of $\delta$, so that equation (13) can be used also for those periods.

We follow the reform descriptions in Section 3 and assign parents with children aged 0 to 4 to the treatment group and parents with children aged 6 to 11 to the control group. In both groups we include respondents who also have older children, but in the control group we do not include respondents who have younger children. We do not use respondents with children who are 5 years old since one could argue that they could belong to either the treatment or to the control group. ${ }^{26}$

Studying two consecutive reforms that were both implemented after the election makes it possible to test if pocketbook voting is prospective or retrospective. Prospective pocketbook voting predicts the support for the Social Democratic Party to decrease among parents with young children in the election of 1994 (due to the proposal to let them finance the budget deficit), to increase in 1998 (due the promise to put a cap on child care fees), and to stay the same in 2002 (since the fee cap reform was implemented as promised). Retrospective voting also predicts a decrease in support for the Social Democratic Party in 1994 (due to the childraising allowance introduced by the centre-right government. In 1998 a further reduction is predicted (due to the abolition of child-raising allowances and the reduction of compensation in the parental insurance), and in 2002 the support is predicted to increase (due to the implementation of the fee cap).

Table 1 displays the predicted voting responses for the prospective and for the retrospective hypotheses. In 1994 both hypotheses predict that parents with children aged 0 to 4 should decrease their support for the left bloc (and for the Social Democratic Party) relative to

\footnotetext{
${ }^{24}$ The Left Party is a small party which has consistently supported Social Democratic minority governments. In the election campaign of 1994, the Left Party made the same promise as the Social Democratic Party to repeal the child-raising allowances and in 1995 they helped the Social Democratic government to do so. In 2000, the Left Party voted with the Social Democratic government to introduce the cap on child care fees.

${ }^{25}$ The centre right parties had consistently been in favor of the benefits they introduced in 1994, but having been in opposition since 1982 they had no opportunity to implement them in any of the previous elections covered in our study. The fact that we present the model in section 2 only for the policy changes by party L is without loss of generality. Any reaction in retrospective voting in favor of new benefits that the centre right parties introduced implies an opposite reaction in the support for the left bloc.

${ }^{26}$ By including respondents with five year old children in the control group, we obtain slightly higher treatment effects, while the opposite happens if we include them in the treatment group.
} 
parents with children aged 6-11. In the election of 1998, the prospective prediction is positive and the retrospective prediction negative. In 2002, only retrospective voting predicts a response, which is positive.

Table 1: Predicted treatment effects

\begin{tabular}{lccc}
\hline Election year & 1994 & 1998 & 2002 \\
Age of children & $0-4$ vs. 6-11 & $0-4$ vs. 6-11 & $0-4$ vs. 6-11 \\
\hline Type of voting & & & \\
Prospective & Negative & Positive & No response \\
Retrospective & Negative & Negative & Positive \\
\hline
\end{tabular}

For our estimations to give unbiased estimates of the treatment effects, two assumptions need to be fulfilled. First, the additive structure of equation (13) must be correct. This assumption is much weaker than assuming a fully linearly additive data generating process, which has been the standard specification in previous empirical studies of economic voting (Lewis-Beck and Stegmaier, 2007). Second, the error term should be uncorrelated with treatment status. The most critical part of this assumption is known as the parallel trend assumption. This means that in absence of the policy changes, the treatment group would have changed its voting pattern just in the same way as the control group did. In practice this means that socioeconomic characteristics that determine party support must be stable within each group over time and that no other policy changes which affect the two groups differently occur at the same time.

To ensure that we can be reasonably confident that these two assumptions are not violated, we have selected the control group to be as similar to the treatment group as possible (more on this in Section 5 and 6). This minimizes the risk that unrelated policy changes or other events affect the two groups differently. Importantly, the control group can be seen as being identical to the treatment group but moved forward in time. As a consequence, we can consider the assignment of parents to the treatment group or to the control group to be as good as random, since it is determined by the year in which their children are born. In section 5 we compare the voting pattern of the treatment and the control group over seven elections to make sure that the parallel trend assumption is not violated. Furthermore, we compare socioeconomic characteristics that are likely to influence voting, both between the groups and within the groups over time, to ensure that they are similar in other relevant respects and also have a stable composition over time. Finally, judging from the election platforms of all Swedish parties from 1982 to 2002, there are no comparable proposals affecting parents belonging to the treatment or to the control group.

We calculate standard errors that are robust to heteroskedasticity and correlation between individuals that appear twice in the data. But, as pointed out by for example Donald and Lang (2007) and Wooldridge (2003), in the presence of unaccounted group-specific shocks and a small number of groups (two in our case), the standard errors are likely to be downward biased. In our case such a problem could arise if the treatment and control groups would be hit by shocks that are correlated within but not across the two groups. In this respect the time pattern of vote shares looks comforting as the early time periods give no reason to believe that our treatment and control groups are exposed to different shocks (see Figure 3 in section 5). Wooldridge (2003) proposes a test for whether group-specific shocks are present. Since the 
test does not reject the null hypothesis that such shocks are absent, we are confident that the presented standard errors of the treatment effects are accurate. ${ }^{27}$

\section{Data and illustrative results}

The availability of high quality data at the individual level constitutes a prerequisite for our empirical strategy. The Swedish Election Studies sample about 3,000 individuals drawn from the population of eligible voters with two exceptions: those living abroad and those older than 80 years. ${ }^{28}$ This data set contains a multitude of background questions about the respondents and their partners, including the number and age of all children in the household. While the secrecy of the ballot unavoidably introduces uncertainty to individual voting data, the Swedish Election Studies have at least two features that make them attractive in international comparisons. First, turnout data from the electoral register is used to verify whether respondents who claimed to have voted actually did. ${ }^{29}$ Being able to exclude respondents who incorrectly claim to have voted eliminates problems associated with over-reporting of turnout, which has been widely discussed in connection with the American National Election Studies; see e.g. Belli et al. (2001). Second, the response rates are high in comparison with other election studies (between 69 and 81 percent in the 1991-2002 Swedish Election Studies).

We first present the support for the left bloc in the general elections from 1982 to 2002, among parents with young and parents with older children. This visual inspection illustrates our empirical strategy and is quite suggestive of prospective pocketbook voting. The formal econometric analysis follows in Section 6.

Figure 3 displays a pattern of prospective pocketbook voting. The support for the left bloc among parents with young children (relative to parents with older children) decreased in 1994 when they were asked to pay for the budget deficit and increased in 1998 when the Social Democrats promised to put a cap on child care fees. The support is more stable in 2002 when no new promises were targeted at this group.

It is evident that retrospective voting is incompatible with the pattern displayed in Figure 3. While the retrospective voting model (as described in Section 4) can be compatible with the 1994 election, it fails to explain voting in 1998 (when it predicts that the benefit cuts will lead to decreasing support for the left bloc among parents with younger children) and in 2002 (when it predicts that the implementation of the fee cap will lead to increasing support for the left bloc among parents with younger children).

According to Figure 3, the voting patterns of the two groups seem to follow the same trend before the 1994 election. This means that in absence of the investigated policy changes it

\footnotetext{
27 When performing Wooldridge's (2003) test we include all years simultaneously in the regressions, giving us seven elections and two groups. We estimate 11 parameters and therefore obtain 3 degrees of freedom. The test statistic is chi-square distributed and equals 0.14 when we study voting for the left bloc and 3.14 when we study voting for the Social Democratic Party alone. We are clearly on the safe side as the critical value at the 10 percent level is 6.25 . On the other hand, by including all elections we risk introducing another source of bias in the standard errors arising from serial correlation, see Bertrand et al (2004). To avoid this problem we present estimates based on two elections at a time.

${ }^{28}$ The election studies are made in the form of a two-step panel in which each respondent is interviewed twice and one half of them are replaced in each study. In the econometric analysis we use this information to cluster standard errors on individuals.

${ }^{29}$ Turnout in the Swedish national elections was 87 percent in 1991 and in 1994, 81 percent in 1998, and 80 percent in 2002 .
} 
seems plausible to assume that our treatment group would have continued to vote in a similar way as the control group. Figure 3 also suggests that the change in the support for the left bloc differ between parents with younger and with older children only in 1994 and 1998. This impression is supported by statistical tests. All three placebo tests on the election pairs 19821985, 1985-1988, and 1988-1991 (using the difference-in-differences approach as described in section 4) produce statistically insignificant treatment effects $(\mathrm{P}>0.1)$, regardless of whether we study votes for the left bloc or votes for the Social Democratic Party. In addition, Appendix $\mathrm{C}$ shows that the voting pattern of parents in the control group (with children between 6 and 11 years old) closely follows the voting pattern of parents with even older children (between 12 and 17 years old). This suggests that we do not identify our treatment effect by unobserved factors affecting our control group only. It also demonstrates that the parents in our 1998 and 2002 control groups do not seem to be affected by having received treatment in the preceding elections.

Figure 3. Vote shares of the left bloc (Social Democratic Party and Left Party) 1982-2002

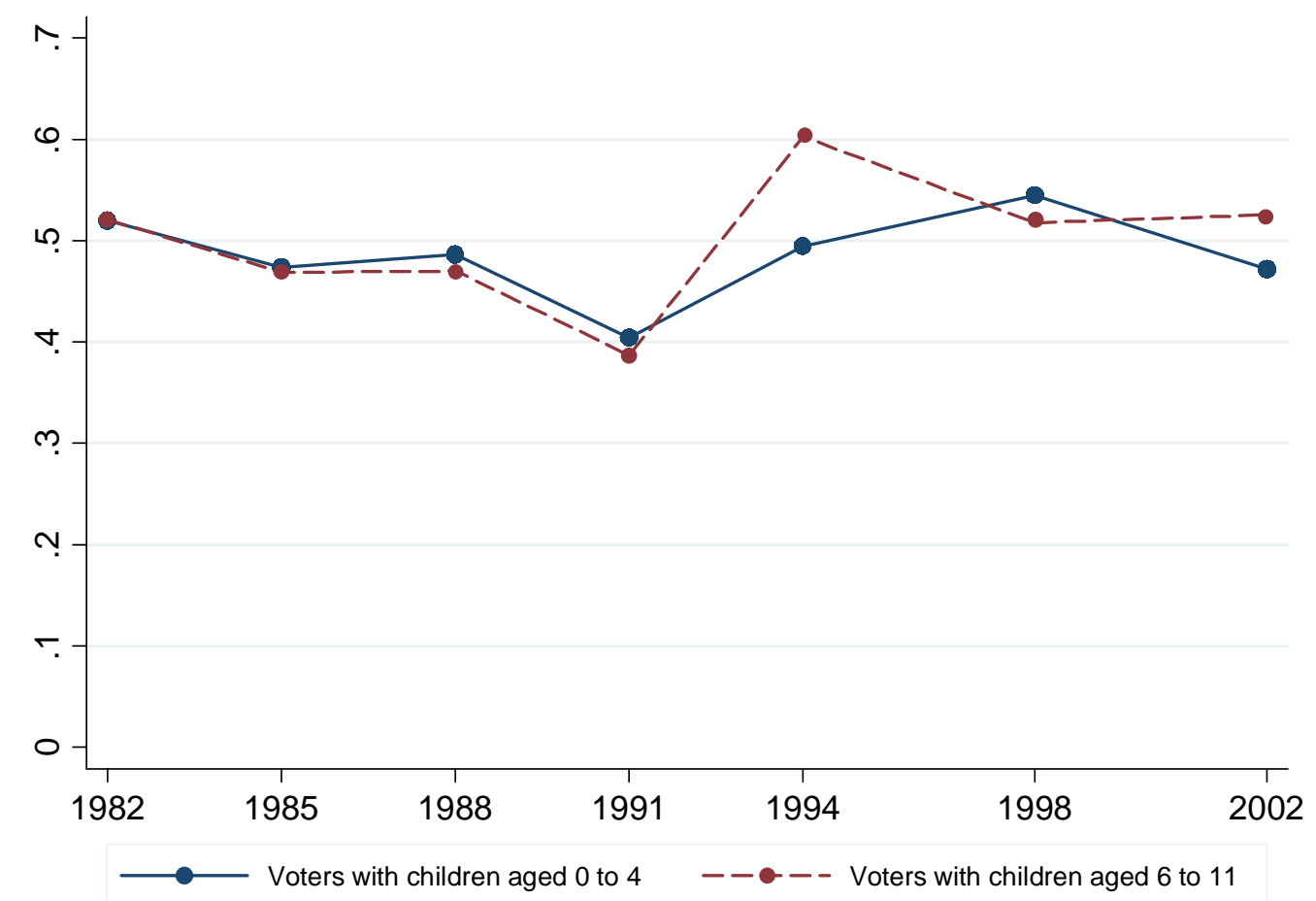

Note: respondents in both groups are allowed to have older children as well, but the respondents in the control group are not allowed to have younger children.

Is it reasonable to believe that the voting pattern displayed in Figure 3 is a result of pocketbook voting? While it is typically not fruitful to ask people whether their vote choice is based on selfish motives, The Swedish Election Studies ask the following open question: "Think about the election this year. Are there any issues that you regard as important when it comes to choosing which party to vote for in the parliamentary election this year?" In 1994 and 1998, 35.9 and 32.0 percent of the respondents with children aged 0 to 4 stated that issues related to family policies were important for their party choice. Interestingly, the corresponding numbers for the control group were 16.6 and 18.9 percent. These numbers point at two interesting patterns. First, a large fraction of parents state that policies directed at themselves are important for their party choice. Second, respondents with older children appear to care less about policies that would have been important to them only a few years 
ago (when their children were younger). Both observations strengthen our interpretation that pocketbook voting is the driving force behind the voting differences between parents with young and parents with older children. The formal testing of this hypothesis is the subject of the next section.

\section{Econometric analysis}

Having inspected the development of the support for the left bloc visually, we now move on to formal econometric testing. By estimating Equation 13 (described in Section 2) we analyze responses to the policy changes (described in Section 3) in the elections of 1994, 1998, and 2002. Recall, that before the 1994 election, the Social Democratic Party proposed several reductions in benefits for parents with young children. The reductions were, with one exception, implemented during the 1994-1998 term of office. Similarly, in the election year of 2002, the Social Democratic Party delivered on their promise from the 1998 election campaign to put a cap on child care fees.

Table 2 contains the difference-in-differences estimates for the left bloc of parties. Column 1 is based on changes in voting behavior between 1991 and 1994. The estimated Treatment effect shows the effect of the reform on the treatment group. The point estimate of -0.126 is statistically significant at the five percent level. This estimate implies that in 1994, the support for the left bloc was 12.6 percentage points lower in the treatment group than it would have been in the absence of any promises or changes in policy. The estimate for Control group $(0.387)$ is in essence an estimate of the fraction of respondents in the control group that voted for the left bloc in 1991. The estimate for Treatment group difference shows that the fraction of respondents in the treatment group that voted for the left bloc in 1991 was 0.404 $(0.387+0.017)$. Time effect is an estimate of the change in support for the left bloc in the control group. While the 1994 treatment effect is consistent with pocketbook voting, it is not possible to distinguish between prospective and retrospective voting from this election only.

In column 2, we look at the 1998 election. In this election the estimated treatment effect equals 0.135 and is again statistically significant at the five percent level. The estimate is consistent with prospective pocketbook voting, but not with voting that is retrospective only. If voting is both prospective and retrospective, the estimate captures the net effect of prospective voting (and implies that retrospective voting is less important).

Column 3 focuses on the election in 2002. Since the fee cap reform was implemented before this election, retrospective voting predicts an increase in the support for the left bloc in the treatment group, whereas no voting response is predicted by the prospective voting hypothesis. If pocketbook voting is prospective, the voters should already have responded to the promise to reduce child care fees in 1998. The estimated treatment effect of -0.080 is not statistically different from zero. Prospective but not retrospective voting is consistent with the 2002 election.

When looking at the three elections together, a striking pattern of prospective pocketbook voting emerges. Pocketbook voting of the prospective type is consistent with the estimated treatment effect in all three elections. In contrast, retrospective voting is inconsistent with the voting pattern over the three elections. Although the negative treatment effect in 1994 could (partly) be due to retrospective voting, the positive treatment effect in 1998 contains at most a small retrospective effect, and the voting behavior in the 2002 election is inconsistent with 
retrospective voting. The same prospective pattern emerges when we use votes for the Social Democratic Party as an alternative dependent variable, as reported in Table 3.

Table 2: Estimates of pocketbook voting for the left bloc of parties

\begin{tabular}{lccc}
\hline Dep. var. Vote for left bloc & $(1)$ & $(2)$ & $(3)$ \\
Election year & 1994 & 1998 & 2002 \\
Age of children & $0-4$ vs. $6-11$ & $0-4$ vs. 6-11 & $0-4$ vs. 6-11 \\
\hline Treatment effect $(\delta)$ & $-0.126^{* *}$ & $0.135^{* *}$ & -0.080 \\
& $(0.060)$ & $(0.067)$ & $(0.069)$ \\
Time effect $(\gamma)$ & $0.215^{* * *}$ & $-0.085^{*}$ & 0.008 \\
& $(0.047)$ & $(0.050)$ & $(0.048)$ \\
Treatment group difference $(\beta)$ & 0.017 & $-0.108^{* *}$ & 0.027 \\
& $(0.043)$ & $(0.046)$ & $(0.050)$ \\
Control group $(\alpha)$ & $0.387^{* * *}$ & $0.602^{* * *}$ & $0.518^{* * *}$ \\
& $(0.035)$ & $(0.038)$ & $(0.036)$ \\
Socioeconomic controls & No & No & No \\
\hline Type of voting & & & Inconsistent \\
Retrospective voting & Consistent & Inconsistent & Consistent \\
Prospective Voting & Consistent & Consistent & 830 \\
\hline Observations & 1,071 & 908 & D
\end{tabular}

Notes: The left bloc includes the Social Democratic Party and the Left Party. The election year of $1994(1998,2002)$ refers to a difference-in-differences estimation of 1994 vs. 1991 (1998 vs. 1994, 2002 vs. 1998). Robust standard errors clustered on individuals in parentheses. * significant at 10\%; $* *$ significant at $5 \%$;** significant at $1 \%$.

Table 3: Estimates of pocketbook voting for the Social Democratic Party (SDP)

\begin{tabular}{llll}
\hline Dep. var. Vote for SDP & $(1)$ & $(2)$ & $(3)$ \\
Election year & 1994 & 1998 & 2002 \\
Age of children & $0-4$ vs. 6-11 & $0-4$ vs. 6-11 & $0-4$ vs. 6-11 \\
\hline Treatment effect $(\delta)$ & $-0.144^{* *}$ & $0.138^{* *}$ & -0.066 \\
& $(0.059)$ & $(0.066)$ & $(0.067)$ \\
Time effect $(\gamma)$ & $0.159^{* * *}$ & $-0.115^{* *}$ & 0.021 \\
& $(0.047)$ & $(0.050)$ & $(0.046)$ \\
Treatment group difference $(\beta)$ & 0.056 & $-0.088^{*}$ & 0.049 \\
& $(0.042)$ & $(0.047)$ & $(0.049)$ \\
Control group $(\alpha)$ & $0.327^{* * *}$ & $0.485^{* * *}$ & $0.371^{* * *}$ \\
& $(0.033)$ & $(0.038)$ & $(0.034)$ \\
Socioeconomic controls & No & No & No \\
\hline Type of voting & & & Inconsistent \\
Retrospective voting & Consistent & Inconsistent & Consistent \\
Prospective Voting & Consistent & Consistent & 830 \\
\hline Observations & 1,071 & 908 & \\
\hline
\end{tabular}

Notes: The election year of 1994 (1998, 2002) refers to a difference-in-differences estimation of 1994 vs.1991 (1998 vs. 1994, 2002 vs. 1998). Robust standard errors clustered on individuals in parentheses. $*$ significant at $10 \% ; * *$ significant at $5 \% ; * * *$ significant at $1 \%$.

If there are significant differences between the treatment and control groups, or if the compositions of the groups change over time, the estimated treatment effect may be biased. We therefore compare demographic and socioeconomic characteristics both between the groups and within the groups over time (see Table A2 and A3 in Appendix A). In our sample the fractions of singles increase over time in both the treatment and control groups. Furthermore, the fraction of unemployed is higher in the treatment groups, which as expected also are younger and have slightly lower income. ${ }^{30}$ As a robustness check we therefore

\footnotetext{
${ }^{30}$ Out of the four elections underlying our difference-in-differences estimates, the income difference between the treatment and the control group is only statistically significant in 1994.
} 
include the demographic and socioeconomic characteristics in the regressions. It turns out that the results are robust to this inclusion. Detailed regression results are found in Table B1-B2 in Appendix B. The stability of our results indicates that our choice of control group is appropriate and strengthens the evidence in favor of pocketbook voting.

The time one child can be in publicly subsidized child care is limited to about five years, as children can attend child care only when they are between one and six years old. This means that when the children have grown old enough to start school, the parents no longer benefit from reduced child care fees. This implies that parents with younger children will benefit from reduced child care fees for a longer period than parents with older children. Also the possibility of a late or even no implementation of the election campaign promise means that the expected value of the reform should decrease in the age of the children. As a further test of our pocketbook voting hypothesis, we have performed a dose response test, using such variation. The point estimates of the dose response test, reported in Appendix D, are in line with our previous results.

Compared with previous studies our analysis embodies several advantages. To start with, most previous studies of pocketbook voting have just assumed a diffuse attribution mechanism: that improved individual finances (or the expectation of this) can be ascribed to the government. This assumption that perceptions about economic outcomes are related to differences in policy between the government and the opposition will at the very least introduce substantial measurement error, and in consequence attenuation bias. The assumption that changes in people's finances are uncorrelated with omitted determinants of voting is even more problematic.

Having a negative treatment followed by a positive treatment for the same group also makes it somewhat more likely that the estimated treatment effect can be generalized to other groups. If the government actively tries to target benefits to the most responsive group (as suggested by models of tactical redistribution), the treatment effect cannot be generalized. Strictly speaking, the estimated treatment effect of each reform can only be generalized to the group of parents that received treatment - but the fact that this group first received a negative and then a positive treatment arguably makes it less likely that it was targeted because its members were unusually responsive.

Our empirical strategy also rules out any confounding influence of the four alternative explanations of voting mentioned in the introduction. First, group voting is not a viable interpretation of the results when group membership is determined by economic gains. In addition, our treatment group - parents with children up to four years old - doesn't resemble any of the groups Mutz and Mondak (1997) work with. Their groups are demarcated by sex, race, labor market participation, income, and self-identification with, or perceived closeness to, a social class.

Second, social background is another possible source of bias. In a seminal contribution, Campbell et al. (1960) claim that party identification is formed early in life through socialization. In our setting, it is conceivable that age differences between the treatment and the (slightly older) control group could capture cohort effects that show up exactly in the elections in which treatment is assigned. While we view such an interpretation as quite far fetched a priori, we address this concern, nonetheless, as it still appears to be the strongest alternative explanation for our findings. 
In particular, the estimated treatment effect in 1994 could be a spurious cohort effect either if the treatment group is unusually right-wing or if the control group is unusually left wing. We know from Figure $\mathrm{C} 1$ in Appendix $\mathrm{C}$ that the control group is not unusually left-wing when compared with parents with even older children aged 12-17. Figure 3 demonstrates the same thing as the "treatment group" of parents with young children in 1991 largely corresponds to the control group of parents with older children in 1994, and there is no difference between the "treatment" and "control" group in 1991. Thus the control group in 1994 does not seem to be an unusual cohort. But the treatment group in 1994 could still be special. In fact, both the estimated treatment effect in 1994 and in 1998 could be spuriously explained by an unusually right-wing treatment group in 1994, since the treatment group in 1994 enters the control group in 1998 as their children grow older. If this were the case, the same group of parents would also stand out in 2002 when their children have grown even older. But Figure C1 displays no such difference in 2002 between parents with children aged 12-17 and parents with children slightly younger than that. To conclude, there is no reason to believe that our empirical results are driven by cohort effects.

Third, we focus on reforms where the voters' attribution problem should be minimal. This leaves little room for different beliefs about the causes of income. Fong (2001) and Alesina and Angeletos (2005) argue that such beliefs shape political preferences for redistribution.

Fourth, our results should be unaffected by macroeconomic conditions; see Fair (1978) for an early test of the electoral impact of such conditions. The reason is simply that the treatment and the control group face the same macroeconomic conditions. So as long as the distribution of individual reactions to the macroeconomic development does not differ between the treatment and the control group, the macroeconomic effects on voting development is captured by the general popularity parameter. And given the minimal voting differences between the treatment group and the control group in all elections before 1994, we see no reason to suspect that the two groups should react differently to the same macroeconomic events. The four alternative theories could obviously play an important role in certain political settings, but none of them should confound our identification of pocketbook voting.

\section{Concluding remarks}

We have presented a theoretical framework for pocketbook voting which results in two testable hypotheses. Our empirical analysis provides clear evidence of prospective pocketbook voting over several elections. This finding stands in sharp contrast to the previous literature where the support for pocketbook voting has been weak overall.

The size of our treatment group implies that the pocketbook effect could be important for election outcomes. According to the Swedish Election Studies, our treatment group made up about 10.8 percent of the electorate (and 11.2 percent of the voters) in 1998. Together with our estimate of the 1998 treatment effect (which is 13.5 percentage points), the share suggests that the promise to put a cap on child care fees increased the support for the left bloc of parties by approximately 1.5 percentage points in the 1998 election. ${ }^{31}$ Although a reform effect of 1.5 percentage points would not have tipped the scales in the 1998 election, it is clear that an effect of this size could affect the balance of power in closer races. The margin between the bloc of left parties and the bloc of centre right parties was less than 1.5 percentage points in

\footnotetext{
${ }^{31}$ The 1.5 percentage point estimate should obviously be taken with great caution. There may for instance be a counterweighing effect if other voters expect their tax burden to increase as a consequence. Note, however, that this qualification doesn't affect our main finding that citizens vote their pocketbooks.
} 
five out of 19 postwar elections. The picture that emerges from our investigation is that pocketbook voting can influence election outcomes, providing a temptation for politicians to tactically redistribute tax revenues to certain groups of voters.

The fee cap reform has been estimated to cost the taxpayers about $€ 360$ million per year. ${ }^{32}$ By dividing this cost with the roughly 80,600 votes (1.5 percent of the total votes) that were swayed by this election promise, we get a crude cost estimate of about $€ 4,500$ per vote annually, corresponding to $€ 18,000$ over a four-year electoral period. Previous studies of pork-barrel spending have estimated the cost of a vote at about $\$ 14,000$ (Levitt and Snyder, 1997) and between $\$ 2,000$ and $\$ 13,000$ (Leigh, 2008). Despite the fact that these studies have analyzed voting at district level, while we use individual-level data, the estimated costs over an electoral term are quite similar in Sweden, Australia, and the United States.

It is important to emphasize that we have only investigated pocketbook voting responses to two salient reforms, and not to other specific policies. As a next step, we believe that our theoretical framework and empirical strategy can be applied to reforms in other countries. Only by directly linking policies with individual gains and votes can pocketbook voting be credibly identified. Finally, since we have studied the case of election campaign promises that were later implemented, it is natural to study two alternative cases in our theoretical model. The first case is that of a campaign promise that is not implemented (or that is implemented to a larger or to a smaller extent than promised). The second case is that of an unexpected implementation of a policy that has not previously appeared as an election campaign promise.

\footnotetext{
${ }^{32}$ According to calculations made by the Ministry of Education and Research (1999) this cost refers to the changes in child care fees that were promised in the 1998 election manifesto and relies on the assumptions that labor supply and child care demand were unaffected by the reform. Since Lundin et al. (2008) have shown that the reform had no effects on labor supply, the cost of the reform is probably underestimated as the reform seems to have increased the demand for child care (Swedish National Agency for Education, 2007).
} 


\section{Appendix A: Description of data}

\section{The Swedish Election Studies}

The variables in our data set are available at The Swedish National Data Service (SND). The data in the Swedish Election Studies were originally collected in a research project at the Department of Political Science at Göteborg University, under the guidance of Sören Holmberg, Mikael Gilljam, and Henrik Oscarsson. Neither SND nor the primary researchers are responsible for the analyses and interpretations presented in this paper. The sample of the Swedish Election Studies is drawn from a population of 18- to 80-year old Swedish citizens entitled to vote in the general election. Citizens living abroad are not included in the sample. The election studies are made in the form of a two-step panel in which each respondent is interviewed twice and one half of them are replaced in each study. The response rates were 82 percent in 1982, 78 percent in 1985, 75 percent in 1988, 73 percent in 1991, 80 percent in 1994, 81 percent in 1998, and 69 percent in 2002.

\section{Description of variables}

Table A1: Description of variables used in the analysis

\begin{tabular}{|c|c|}
\hline Variable & Definition \\
\hline Vote for left bloc & $\begin{array}{l}1 \text { if voted for the Social Democratic Party or the Left } \\
\text { party; } 0 \text { otherwise. }\end{array}$ \\
\hline Vote for the Social Democratic Party & $\begin{array}{l}1 \text { if voted for the Social Democratic Party; } 0 \\
\text { otherwise. }\end{array}$ \\
\hline Sex & 1 if female; 0 if male \\
\hline Marital status & $\begin{array}{l}1 \text { if single; } 0 \text { if married with or cohabiting with } \\
\text { another adult. }\end{array}$ \\
\hline Two children & $\begin{array}{l}1 \text { if there are two children under age } 18 \text { living in the } \\
\text { household; } 0 \text { otherwise. }\end{array}$ \\
\hline Three or more children & 1 if there are three or more children under age 18 \\
\hline Income $(€ 1,000)$ & $\begin{array}{l}\text { living in the household; } 0 \text { otherwise. } \\
\text { Gross earnings, referring to the income year two years } \\
\text { prior to the survey year. Register based. Source: } \\
\text { Statistics Sweden. }\end{array}$ \\
\hline Age & Years of age \\
\hline
\end{tabular}

Source: The Swedish Election Studies. 


\section{Descriptive statistics}

Table A2. Variable means for the treatment groups (parents with children aged 0 to 4 years old)

\begin{tabular}{lcccc}
\hline & 1991 & 1994 & 1998 & 2002 \\
\hline Vote for left bloc & 40.4 & 49.4 & 54.5 & 47.2 \\
Vote for SDP & $(35.3-45.7)$ & $(44.0-54.9)$ & $(47.3-61.5)$ & $(40.4-54.1)$ \\
& 38.2 & 39.7 & 42.0 & 37.5 \\
Sex $(1=$ female) & $(33.2-43.5)$ & $(34.5-45.1)$ & $(35.1-49.2)$ & $(31.0-44.3)$ \\
& 0.48 & 0.53 & 0.53 & 0.52 \\
Marital status $(1=$ single) & $(0.43-0.53)$ & $(0.47-0.58)$ & $(0.45-0.60)$ & $(0.45-0.59)$ \\
& 0.031 & 0.047 & 0.055 & 0.074 \\
Unemployed & $(0.015-0.054)$ & $(0.027-0.075)$ & $(0.028-0.096)$ & $(0.043-0.118)$ \\
& 0.033 & 0.103 & 0.085 & 0.069 \\
Two children & $(0.017-0.057)$ & $(0.073-0.140)$ & $(0.050-0.133)$ & $(0.039-0.11)$ \\
Three or more children & 0.41 & 0.41 & 0.51 & 0.42 \\
& $(0.36-0.46)$ & $(0.36-0.46)$ & $(0.43-0.58)$ & $(0.35-0.49)$ \\
Income $(€ 1,000)$ & 0.25 & 0.26 & 0.18 & 0.22 \\
Age & $(0.21-0.30)$ & $(0.22-0.31)$ & $(0.13-0.24)$ & $(0.17-0.28)$ \\
& 18.4 & 18.0 & 20.8 & 27.0 \\
\hline Observations & $(17.2-19.6)$ & $(17.0-19.1)$ & $(18.7-22.9)$ & $(19.0-35.0)$ \\
\hline
\end{tabular}

Note: $95 \%$ confidence intervals in parentheses

Table A3. Variable means for the control groups (parents with children aged 6 to 11 years old)

\begin{tabular}{lcccc}
\hline & 1991 & 1994 & 1998 & 2002 \\
\hline Vote for left bloc & 38.7 & 60.2 & 51.8 & 52.5 \\
Vote for SDP & $(31.9-45.8)$ & $(52.4-67.6)$ & $(44.6-58.9)$ & $(45.7-59.3)$ \\
& 32.7 & 48.5 & 37.1 & 39.2 \\
Sex $(1=$ female) & $(26.2-39.7)$ & $(40.8-56.3)$ & $(30.3-44.2)$ & $(32.6-46.0)$ \\
& 0.48 & 0.40 & 0.47 & 0.49 \\
Marital status $(1=$ single) & $(0.41-0.55)$ & $(0.33-0.48)$ & $(0.40-0.54)$ & $(0.42-0.56)$ \\
& 0.060 & 0.099 & 0.157 & 0.198 \\
Unemployed & $(0.032-0.103)$ & $(0.059-0.154)$ & $(0.110-0.216)$ & $(0.147-0.257)$ \\
& 0.020 & 0.047 & 0.036 & 0.051 \\
Two children & $(0.005-0.051)$ & $(0.020-0.090)$ & $(0.014-0.071)$ & $(0.026-0.089)$ \\
& 0.50 & 0.54 & 0.50 & 0.51 \\
Three or more children & $(0.43-0.57)$ & $(0.36-0.61)$ & $(0.43-0.57)$ & $(0.44-0.58)$ \\
Income $(€ 1,000)$ & 0.24 & 0.20 & 0.26 & 0.28 \\
Age & $(0.18-0.31)$ & $(0.15-0.27)$ & $(0.20-0.33)$ & $(0.22-0.34)$ \\
& 19.9 & 20.6 & 21.1 & 23.7 \\
\hline Observations & $(18.6-21.2)$ & $(18.9-22.3)$ & $(19.5-22.6)$ & $(20.9-26.4)$ \\
\hline Note: 95\% confidence intervals in parentheses & 41.4 & 40.5 & 39.3 & 40.0 \\
& $(40.6-42.3)$ & $(39.5-41.5)$ & $(38.2-40.3)$ & $(39.0-41.0)$ \\
\hline
\end{tabular}

Note: $95 \%$ confidence intervals in parentheses 


\section{Appendix B: Robustness checks}

Including demographic and socioeconomic characteristics in the difference-in-difference estimations

Table B1. Pocketbook voting: 1994, 1998 \& 2002 including demographic and socioeconomic controls

\begin{tabular}{|c|c|c|c|}
\hline Dep. var. Vote for left bloc & $(1)$ & $(2)$ & (4) \\
\hline Election year & 1994 & 1998 & 2002 \\
\hline Age of children & $0-4$ vs. $6-11$ & $0-4$ vs. $6-11$ & $0-4$ vs. $6-11$ \\
\hline \multirow[t]{2}{*}{ Treatment effect $(\delta)$} & $-0.128 * *$ & $0.151 * *$ & -0.063 \\
\hline & $(0.060)$ & $(0.066)$ & $(0.069)$ \\
\hline \multirow{2}{*}{ Time effect $(\gamma)$} & $0.208 * * *$ & $-0.091 *$ & 0.009 \\
\hline & $(0.047)$ & $(0.050)$ & $(0.048)$ \\
\hline \multirow[t]{2}{*}{ Treatment group difference $(\beta)$} & -0.022 & $-0.150 * * *$ & -0.005 \\
\hline & $(0.050)$ & $(0.051)$ & $(0.054)$ \\
\hline \multirow[t]{2}{*}{ Control group $(\alpha)$} & $0.621 * * *$ & $0.866 * * *$ & $0.714 * * *$ \\
\hline & $(0.126)$ & $(0.129)$ & $(0.123)$ \\
\hline \multirow[t]{2}{*}{ Sex $(1=$ female $)$} & 0.005 & -0.006 & 0.000 \\
\hline & $(0.037)$ & $(0.040)$ & $(0.037)$ \\
\hline \multirow[t]{2}{*}{ Marital status $(1=$ single $)$} & 0.059 & $0.119 * *$ & 0.068 \\
\hline & $(0.066)$ & $(0.061)$ & $(0.055)$ \\
\hline \multirow[t]{2}{*}{ Unemployed } & $0.157 * *$ & 0.084 & 0.112 \\
\hline & $(0.066)$ & $(0.062)$ & $(0.072)$ \\
\hline \multirow[t]{2}{*}{ Two children } & -0.008 & 0.061 & 0.063 \\
\hline & $(0.036)$ & $(0.040)$ & $(0.041)$ \\
\hline \multirow[t]{2}{*}{ Three or more children } & -0.054 & -0.015 & 0.044 \\
\hline & $(0.044)$ & $(0.050)$ & $(0.050)$ \\
\hline \multirow[t]{2}{*}{ Income $(€ 1,000)$} & $-0.005 * * *$ & $-0.005 * * *$ & $-0.001 * *$ \\
\hline & $(0.001)$ & $(0.001)$ & $(0.001)$ \\
\hline \multirow[t]{2}{*}{ Age } & -0.003 & $-0.005^{*}$ & $-0.006^{* *}$ \\
\hline & $(0.003)$ & $(0.003)$ & $(0.003)$ \\
\hline \multicolumn{4}{|l|}{ Type of voting } \\
\hline Retrospective voting & Consistent & Inconsistent & Inconsistent \\
\hline Prospective voting & Consistent & Consistent & Consistent \\
\hline Observations & 1,070 & 908 & 830 \\
\hline
\end{tabular}


Table B2. Pocketbook voting: 1994, 1998 \& 2002 including demographic and socioeconomic controls

\begin{tabular}{|c|c|c|c|}
\hline $\begin{array}{l}\text { Dep. var. Vote for the Social } \\
\text { Democratic Party }\end{array}$ & (1) & (2) & (4) \\
\hline Election year & 1994 & 1998 & 2002 \\
\hline Age of children & $0-4$ vs. $6-11$ & $0-4$ vs. $6-11$ & $0-4$ vs. $6-11$ \\
\hline Treatment effect $(\delta)$ & $\begin{array}{l}-0.150 * * \\
(0.060)\end{array}$ & $\begin{array}{l}0.132 * * \\
(0.066)\end{array}$ & $\begin{array}{l}-0.055 \\
(0.067)\end{array}$ \\
\hline Time effect $(\gamma)$ & $\begin{array}{c}0.155^{* * *} \\
(0.047)\end{array}$ & $\begin{array}{c}-0.110 * * \\
(0.050)\end{array}$ & $\begin{array}{c}0.028 \\
(0.047)\end{array}$ \\
\hline Treatment group difference $(\beta)$ & $\begin{array}{c}0.028 \\
(0.049)\end{array}$ & $\begin{array}{c}-0.108 * * \\
(0.052)\end{array}$ & $\begin{array}{c}0.010 \\
(0.054)\end{array}$ \\
\hline Control group $(\alpha)$ & $\begin{array}{c}0.501 * * * \\
(0.124)\end{array}$ & $\begin{array}{l}0.626 * * * \\
(0.129)\end{array}$ & $\begin{array}{l}0.540 * * * \\
(0.124)\end{array}$ \\
\hline $\operatorname{Sex}(1=$ female $)$ & $\begin{array}{c}0.002 \\
(0.036)\end{array}$ & $\begin{array}{l}-0.014 \\
(0.039)\end{array}$ & $\begin{array}{l}-0.004 \\
(0.036)\end{array}$ \\
\hline Marital status $(1=$ single $)$ & $\begin{array}{l}-0.037 \\
(0.069)\end{array}$ & $\begin{array}{l}-0.024 \\
(0.063)\end{array}$ & $\begin{array}{r}-0.093 * \\
(0.052)\end{array}$ \\
\hline Unemployed & $\begin{array}{l}0.134^{*} \\
(0.070)\end{array}$ & $\begin{array}{c}0.049 \\
(0.065)\end{array}$ & $\begin{array}{c}0.058 \\
(0.072)\end{array}$ \\
\hline Two children & $\begin{array}{l}-0.005 \\
(0.037)\end{array}$ & $\begin{array}{c}0.062 \\
(0.040)\end{array}$ & $\begin{array}{l}0.071^{*} \\
(0.041)\end{array}$ \\
\hline Three or more children & $\begin{array}{l}-0.054 \\
(0.043)\end{array}$ & $\begin{array}{l}-0.040 \\
(0.047)\end{array}$ & $\begin{array}{c}0.021 \\
(0.049)\end{array}$ \\
\hline Income $(€ 1,000)$ & $\begin{array}{l}-0.004 * * * \\
(0.001)\end{array}$ & $\begin{array}{l}-0.002 \\
(0.001)\end{array}$ & $\begin{array}{l}-0.001 * * \\
(0.000)\end{array}$ \\
\hline Age & $\begin{array}{l}-0.002 \\
(0.003) \\
\end{array}$ & $\begin{array}{l}-0.003 \\
(0.003)\end{array}$ & $\begin{array}{l}-0.005 \\
(0.003)\end{array}$ \\
\hline Type of voting & & & \\
\hline $\begin{array}{l}\text { Retrospective voting } \\
\text { Prospective voting }\end{array}$ & $\begin{array}{l}\text { Consistent } \\
\text { Consistent }\end{array}$ & $\begin{array}{l}\text { Inconsistent } \\
\text { Consistent }\end{array}$ & $\begin{array}{c}\text { Inconsistent } \\
\text { Consistent }\end{array}$ \\
\hline Observations & 1,070 & 908 & 830 \\
\hline
\end{tabular}


Appendix C: Voting among parents in the control group and among parents with even older children

Figure C1. Vote shares of the left bloc (Social Democratic Party and Left Party) 1982-2002

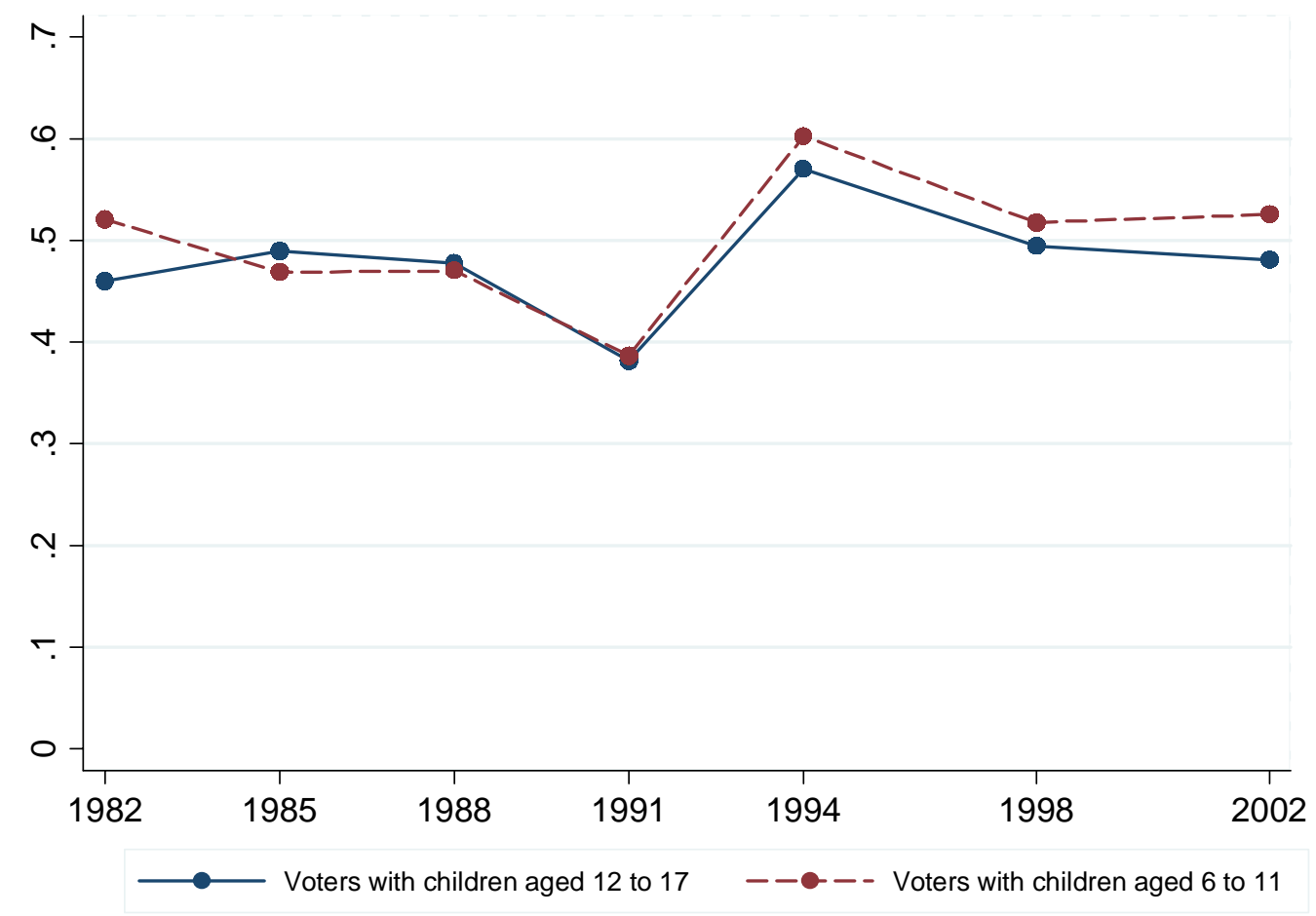

Note: The figure shows voting among our control group of parents with children 6 to 11 years old and among parents with children 12 to 17 years old. None of the respondents in the two groups are allowed to have younger children. 


\section{Appendix D: Dose response test}

As a natural extension of our empirical tests of pocketbook voting we test for a dose response relationship. If we find that voters with children aged 0 to 2 respond more strongly to the promise of a cap on child care fees than voters with children aged 3 to 5 , it would be strong evidence in favor of a causal relationship between pocketbook promises and voting. ${ }^{33}$ Table 4 presents the results from such a test. Since this test divides the treatment group into two parts and estimates two more parameters, the power of the test will unavoidably be quite low. For this reason we include respondents with five year old children in the treatment group. The point estimates of the treatment effects follow the pattern predicted by prospective pocketbook voting. The point estimate is higher among parents with the youngest children who received the largest benefits from the fee cap. The precision of the estimates is, however, too low to conclude that they are different from each other at normal levels of statistical significance. Thus, the dose response test doesn't provide strong evidence in favor of prospective pocketbook voting, but neither does it contradict our previous findings.

Table D1: Dose response test for prospective voting in 1998

\begin{tabular}{lc}
\hline Dep. var. Vote for the left bloc & $(1)$ \\
& $0-2$ vs. $3-5$ vs. $6-11$ \\
\hline Treatment effect $3-5$ & 0.068 \\
& $(0.084)$ \\
Treatment effect $0-2$ & 0.098 \\
& $(0.074)$ \\
$\Delta$ 3-5 vs. control 1994 & -0.034 \\
& $(0.054)$ \\
$\Delta$ 0-2 vs. control 1994 & $-0.143^{* * *}$ \\
Time effect (1994-1998) & 0.068 \\
& $-0.085^{*}$ \\
Control group & $(0.050)$ \\
& $0.602^{* * *}$ \\
\hline Observations & $(0.038)$ \\
\hline
\end{tabular}

Notes: The election year of 1998 refers to a difference-in-differences estimation of 1998 vs 1994. Robust standard errors clustered on individuals in parentheses. $*$ significant at $10 \% ; *$ significant at $5 \% ; * * *$ significant at $1 \%$.

\footnotetext{
${ }^{33}$ Comparing parents with one and parents with two or more children in child care would be a less convincing dose response test. On the one hand, additional children mean higher momentary gains from the reform. On the other hand, since many parents with one child plan to have more children, they can expect to enjoy the fruits of the reform for a longer period of time in the future.
} 


\section{References}

Alesina, Alberto and George-Marios Angeletos (2005). "Fairness and redistribution: US vs. Europe." American Economic Review, 95 (4): 960-980.

Alvarez, R. Michael and Jonathan Nagler (1995). "Economics, issues and the Perot candidacy: Voter choice in the 1992 presidential election." American Journal of Political Science, 39 (3): 714-744.

Alvarez, R. Michael and Jonathan Nagler (1998). "Economics, entitlements, and social issues: Voter change in the 1996 presidential election." American Journal of Political Science, 42 (4): 1349-1363.

Arter, David (1999). "The Swedish general election of 20th September 1998: A victory for values over policies?" Electoral Studies, 18 (2): 296-300.

Belli, Robert, Michael Trogott, and Matthew Beckmann (2001). "What leads to voting overreports? Contrasts of overreporters to validated voters and admitted nonvoters in the American National Election Studies.” Journal of Official Statistics, 17 (4): 479-498.

Bertrand, Marianne, Esther Duflo, and Sendhil Mullainathan (2004). "How much should we trust differences-in-differences estimates?" The Quarterly Journal of Economics 119 (1): 249-275.

Besley, Timothy (2006). Principled Agents? The Political Economy of Good Government. Oxford: Oxford University Press.

Buchanan, James and Gordon Tullock (1962). The Calculus of Consent. Ann Arbor: University of Michigan Press.

Campbell, Angus, Philip Converse, Warren Miller, and Donald Stokes (1960). The American Voter. New York: Wiley.

Dahlberg, Matz and Eva Johansson (2002). "On the vote purchasing behavior of incumbent governments.” American Political Science Review, 96 (1), 27-40.

Dixit, Avinash and John Londregan (1996). "The determination of success of special interests in redistributive politics." Journal of Politics, 58 (4): 1132-1155.

Donald, Stephen G. and Kevin Lang (2007). "Inference with difference-in-differences and other panel data." Review of Economics and Statistics 89 (2): 221-233.

Downs, Anthony (1957). An Economic Theory of Democracy. New York: Harper and Row Publishers.

Edlund, Lena and Rohini Pande (2002). "Why have women become left-wing: The political gender gap and the decline in marriage." Quarterly Journal of Economics, 117 (3): 917-961.

Fair, Ray C. (1978). "The effect of economic events on votes for president." Review of Economics and Statistics, 60 (2): 159-173. 
Fiorina, Morris, P. (1978). "Economic retrospective voting in American national elections: A micro-analysis." American Journal of Political Science, 22 (2): 426-443.

Fiorina, Morris, P. (1981). Retrospective Voting in American National Elections. New Haven: Yale University Press.

Fong, Christina M. (2001). "Social preferences, self-interest, and the demand for redistribution." Journal of Public Economics, 82 (2): 225-246.

Gomez, Brad and Matthew Wilson (2001). "Political sophistication and economic voting in the American electorate: A theory of heterogeneous attribution." American Journal of Political Science, 45 (4): 899-914.

Hibbs, Douglas (2006). "Voting and the macroeconomy," in Barry Weingast and Donald Wittman, (eds.) The Oxford Handbook of Political Economy, Oxford: Oxford University Press, chapter 31: 565-586.

Jordahl, Henrik (2006). "An economic analysis of voting in Sweden." Public Choice, 127 (3-4): 251-265.

Key, Vladimir Orlando. (1966). The Responsible Electorate. Cambridge, MA: Harvard University Press.

Kinder, Donald R. and D. Roderick Kiewiet. (1979). "Economic discontent and political behavior: The role of personal grievances and collective economic judgments in congressional voting." American Journal of Political Science, 23 (3): 495-527.

Leigh, Andrew (2008). "Bringing home the bacon." Public Choice, forthcoming.

Levitt, Steven and James M. Snyder (1997). "The impact of federal spending on house election outcomes." Journal of Political Economy, 105 (1): 30-53.

Lewis-Beck, Michael S. and Mary Stegmaier (2007). "Economic models of voting." In Russel Dalton and Hans-Dieter Klingemann (eds.), The Oxford Handbook of Political Behavior. Oxford: Oxford University Press: 518-537.

Lindbeck, Assar and Jörgen Weibull (1987). "Balanced-budget redistribution as the outcome of political competition." Public Choice, 52 (3): 273-297.

Lundin, Daniella., Eva Mörk, and Björn Öckert (2008). "How far can reduced childcare prices push female labour supply?” Labour Economics, 15 (4): 647-659.

MacKuen, Michael B., Robert S. Erikson, and James A. Stimson (1992). "Peasants or bankers? The American electorate and the U.S. economy." American Political Science Review, 86 (3): 597-611.

Markus, Gregory B. (1988). "The impact of personal and national economic conditions on the presidential vote: A pooled cross-section analysis." American Journal of Political Science, 32 (1): 137-154.

Markus Gregory B. (1992). "The impact of personal and national economic conditions on presidential voting, 1956-1988." American Journal of Political Science, 36 (3): 829-834. 
Meltzer, Allan H. and Scott. F. Richard (1981). "A rational theory of the size of government." Journal of Political Economy, 89 (5): 914-927.

Miller, Arthur and Martin Wattenberg (1985). "Throwing the rascals out: Policy and performance evaluation of presidential candidates, 1952-1980." American Political Science Review, 79 (2): 359-372.

Ministry of Education and Research (1999). "Maxtaxa och allmän förskola." [Maximum fees and public child care], Ds 1999:53.

Mutz, Diana C. and Jeffrey J. Mondak (1997). "Dimensions of sociotropic behavior: Groupbased judgments of fairness and well-being." American Journal of Political Science, 41 (1): 284-308.

Nadeau, Richard and Michael S. Lewis-Beck (2001). "National Economic Voting in U.S. Presidential Elections." Journal of Politics, 63 (1): 159-181.

Naurin, Elin (2008). The Promising Democracy: Parties, Citizens and Election Promises. Dissertation manuscript, Department of Political Science, University of Gothenburg.

Persson, Torsten and Guido Tabellini (2000). Political Economics: Explaining Economic Policy. Cambridge, MA: MIT Press.

Richter, Kaspar (2006). "Wage arrears and economic voting in Russia." American Political Science Review, 100 (1): 133-145.

Rogoff, Kenneth (2000). "Equilibrium political budget cycles." American Economic Review, 80 (1): $21-36$.

Royed, Terry (1996). "Testing the mandate model in Britain and the United States: Evidence from the Reagan and Thatcher eras." British Journal of Political Science, 26 (1): 45-80.

Sibert, Anne and Kenneth Rogoff (1988). "Elections and macroeconomic policy cycles." Review of Economic Studies, 55 (1): 1-16.

Swedish National Agency for Education (1999). "Avgifter i förskola och fritidshem 1999." [Fees in child care and after school recreation centers 1999], report 174.

Swedish National Agency for Education (2003). "Avgifter i förskola och fritidshem 2003." [Fees in child care and after school recreation centers 2003], supplement to report 231.

Swedish National Agency for Education (2007). "Five years with the maximum fee." English summary of report 294.

Widfeldt, Anders (1995). "The Swedish parliamentary election of 1994." Electoral Studies 14 (2): 206-212.

Wooldridge, Jeffrey M. (2003). "Cluster-sample methods in applied econometrics." American Economic Review, 93 (2): 133-138. 
WORKING PAPERS*

Editor: Nils Gottfries

2007:8 Marcus Eliason and Henry Ohlsson, Living to Save Taxes. 13pp.

2007:9 Åsa Ahlin and Eva Mörk, Effects of decentralization on school resources: Sweden 1989-2002. 31pp.

2007:10 Henry Ohlsson, The equal division puzzle - empirical evidence on intergenerational transfers in Sweden. 20pp.

2007:11 Daniel Hallberg and Mårten Lagergren, Moving in and out of public geriatric care in Sweden. 26pp.

2007:12 Per Engström, Wage Formation and Redistribution. 22pp.

2007:13 Henry Ohlsson, Tax avoidance - a natural experiment. 21pp.

2007:14 David Kjellberg and Erik Post, A Critical Look at Measures of Macroeconomic Uncertainty. 27pp.

2007:15 Mikael Carlsson and Andreas Westermark, Optimal Monetary Policy under Downward Nominal Wage Rigidity. 52pp.

2007:16 Robin Douhan and Anders Nordberg, Is the elephant stepping on its trunk? The problem of India's unbalanced growth. 33pp.

2007:17 Annika Alexius and Bertil Holmlund, Monetary Policy and Swedish Unemployment Fluctuations. 27pp.

2007:18 Meredith Beechey and Pär Österholm, The Rise and Fall of U.S. Inflation Persistence. 23pp.

2007:19 Henry Ohlsson and Donald Storrie, Long term effects of public policy for displaced workers in Sweden - shipyard workers in the West and miners in the North. 26pp.

2007:20 Niklas Bengtsson, How responsive is body weight to transitory income changes? Evidence from rural Tanzania. 38pp.

2007:21 Karin Edmark, Strategic Competition in Swedish Local Spending on Childcare, Schooling and Care for the Elderly. 38pp.

2007:22 Fredrik Johansson, How to Adjust for Nonignorable Nonresponse: Calibration, Heckit or FIML? 25pp.

2007:23 Henry Ohlsson, The legacy of the Swedish gift and inheritance tax, 18842004. 25pp.

\footnotetext{
* A list of papers in this series from earlier years will be sent on request by the department.
} 
2007:24 Ranjula Bali Swain and Fan Yang Wallentin, DOES MICROFINANCE EMPOWER WOMEN? Evidence from Self Help Groups in India. 26pp.

2007:25 Bertil Holmlund and Martin Söderström, Estimating Income Responses to Tax Changes: A Dynamic Panel Data Approach. 34pp.

2007:26 N. Anders Klevmarken, Simulating the future of the Swedish baby-boom generations. 60pp.

2007:27 Olof Åslund and Oskar Nordström Skans, How to Measure Segregation Conditional on the Distribution of Covariates. 17pp.

2007:28 Che-Yuan Liang, Is There an Incumbency Advantage or a Cost of Ruling in Proportional Election Systems? 20pp.

2007:29 Stefan Eriksson and Jonas Lagerström, Detecting discrimination in the hiring process: Evidence from an Internet-based search channel. 31pp.

2007:30 Helge Berger and Pär Österholm, Does Money Growth Granger-Cause Inflation in the Euro Area? Evidence from Out-of-Sample Forecasts Using Bayesian VARs. 32pp.

2007:31 Ranjula Bali Swain and Maria Floro, Effect of Microfinance on Vulnerability, Poverty and Risk in Low Income Households. 35pp.

2008:1 Mikael Carlsson, Johan Lyhagen and Pär Österholm, Testing for Purchasing Power Parity in Cointegrated Panels. 20pp.

2008:2 Che-Yuan Liang, Collective Lobbying in Politics: Theory and Empirical Evidence from Sweden. 37pp.

2008:3 Spencer Dale, Athanasios Orphanides and Pär Österholm, Imperfect Central Bank Communication: Information versus Distraction. 33pp.

2008:4 Matz Dahlberg and Eva Mörk, Is there an election cycle in public employment? Separating time effects from election year effects. 29pp.

2008:5 Ranjula Bali Swain and Adel Varghese, Does Self Help Group Participation Lead to Asset Creation. 25pp.

2008:6 Niklas Bengtsson, Do Protestant Aid Organizations Aid Protestants Only? 28pp.

2008:7 Mikael Elinder, Henrik Jordahl and Panu Poutvaara, Selfish and Prospective Theory and Evidence of Pocketbook Voting. 31 pp.

See also working papers published by the Office of Labour Market Policy Evaluation http://www.ifau.se/ 